\title{
İkinci Dünya Savaşı'Inda Türk Hükümetlerinin Temel Gıda Maddelerinin Temini Konusunda Aldığı Tedbirler
}

\author{
Yrd. Doç. Dr. Șinasi SÖNMEZ*
}

\begin{abstract}
$\ddot{O z e t}$
Ikinci Dünya Savaşı, dünya tarihinde en büyük insan kayıplarının yaşandığı bir felaket olarak tarihte yerini alırken aynı zamanda iktisadi, siyasal, sosyal felaketlerin de yaşanmasına neden olmuştur. Türkiye savaşın dışında kalmasına rağmen iktisadî olarak derinden etkilenen ülkelerden biridir. Savaş süresince Türkiye, gücünün ve ihtiyacının üstünde bir ordu bulundurmak ve bu ordunun gereksinimlerini karşılamak için sıkıntılarla karşılaşmış, bu sıkıntıları gidermek uğruna olă̆anüstü tedbirler almıştır. Bir yandan azalan ihracatından doğan nakit ihtiyacını olağanüstü vergilerle karşılamaya çalışırken, bir yandan da halkın en temel besin maddesi olan ekmeği karneye bağlamış, toplu bir açlık tehlikesinin önüne geçmeye çalışmıştır. Temel gıda maddelerinin temini ve dağıtımı dönem hükümetlerinin en önemli icraatlarından biri olmuştur.
\end{abstract}

Anahtar Kelimeler: Ikkinci Dünya Savaşı, temel gıda maddeleri, Bakanlar Kurulu Kararlarl, ekmek karnesi

\section{The Measures Taken By Turkish Governments For Supplying Basic Foodstuff During World War II}

\begin{abstract}
World War II caused the largest human loses in the world history and has taken its place as a catastrophe in history, but also it has led to the emergence of economic, social and political crises throughout the world. Although Turkey stayed out of the war, she was deeply affected by the economic crises. Turkey encountered with economic difficulties from having an army that exceeded its needs and economic power during the war. Turkey has taken extraordinary measures to meet
\end{abstract}

\footnotetext{
*Zonguldak Karaelmas Üniversitesi, Ereğli Eğitim Fakültesi.
} 
its cash need that arising from declining exports, and levied extraordinary taxes, the basic foodstuff, bread, was sold by card in order to avoid the danger of mass starvation. The supply and distribution of the basic foodstuffs were one of the most important performances of governments.

Key Words: Turkey during the Second World War, basic foods, cabinet, decisions, bread reports

\section{GíRiş}

Kurtuluş Savaşı'nın hemen ardından daha Lozan Antlaşması'nın müzakere edildiği sırada, ülkede nasıl bir iktisadî yol izleyeceğini belirmek için İzmir İktisat Kongresi düzenlenmiştir. Kongrede alınan kararlarda esas olarak ülkenin üretim potansiyelini harekete geçirerek iktisadi gelişmesinin ana çerçevesini belirleme amacının yanı sıra, yönetim iktisadi kalkınmanın temel önceliklerinden biri olduğunu daha o günden ortaya koymuştur. Türkiye Cumhuriyeti kadroları 1929 yılına kadar Osmanlıdan kalan dış borçlarını ödemede bir takvime bağlama uğraşının yanında devlet gelirlerinin ana unsuru olan vergi düzenleme, gümrüklerini kendi istediği biçimde kullanma ve yönetmede bağımsız hareket etme uğraşını vermiştir. İçeride üretimin arttırılması, yetersiz olsa bile üretilen malların dış pazara sevkinin koşularını hazırlamaya çalıştığı bu dönemde bir başka sorunla karşı karşıya kalmıştır.

1929 'da dünyada meydana gelen ekonomik kriz, diğer ülkeleri olduğu gibi ekonomisi düzene girme yolunda olan Türkiye'yi de derinden etkilemiştir. Önceki dönemden devraldığı sorunlara dış pazarının daralması da eklenince dönem hükümetleri yeni arayışlara girmiştir. 1931 yılından itibaren resmen tek parti dönemine geçerken ekonomik kalkınmasında da yeni arayıșlara girmiștir. Halkın geçim sıkıntısının üst düzeylere çıktığı bu dönemlerde hükümet "tasarruf" ve "yerli malı" kavramlarını ön plana çıkararak halkı günlük tüketiminde daha az ve yerli malları tüketmeye teşvik etmiştir. Yönetimin kendisi de tasarruf yaparak kamu harcamalarını kısma yoluna gitmiş, 63 olan vilayet sayısını 45'e indirmiş, Dışişleri Bakanlığı'nda çalışan memurların elbiselerinin yerli malı olmas ${ }^{1}$ gibi tedbirlere başvurmuştur. Ekonomide ise planlı kalkınma yolunu seçerek belli aralıklarda ulaşılabilecek hedefler konmuştur. İki defa, her biri beş yıllık

${ }^{1}$ Bülent Duru; "1931 Tasarruf Yıl1: Tek Partili Dönemin Başlangıcı”, Türkiye Cumhuriyeti İdare Tarihi Araştırması (T.D.ATA), A.Ü. Siyasal Bilgiler Fakültesi Kamu Yönetimi Araştırma ve Uygulama Merkezi 2, Ankara, 2007, s. 209-302. 
olarak uygulanan, planlı kalkınma süresinin İkinci Dünya Savaşı'nın başlaması ile ikinci defa uygulanması savaş boyunca ertelenmiştir.

Türkiye'nin iktisadi kalkınmayı gerçekleştirmeye yönelik devletçi kalkınma modelini uyguladığı yıllarda İkinci Dünya Savaşı'nın başlaması ve yol açtığı gelişmeler hesapta olmayan sıkıntıları doğurmuştur. Her şeyden önce silahlı kuvvetlerin sayısını iki katına çıarmak ve ihtiyaçlarını karşılamak için silah ve diğer malzemeler ile askerin doyurulması gibi harcamaları karşılamak zorunda kalmıştır. Savaşın dışında kalmasına rağmen, iş gücü sayısının büyük bölümünün silâhaltına alınması, ithalat ve ihracatının daralması üretim kayıplarına yol açarken halkın ve ordunun temel gıda maddelerini karşılamakta dönem hükümetleri büyük zorluklarla karşılaşmıştır. Bu güç koşulların üstesinden gelmek için 18.01.1940 tarihinde çıkarılan Milli Korunma Kanunu'nun gerekçesi şöyle açıklanmıştır:

“Son zamanlarda Avrupa'da hüküm sürmekte olan siyasi gerginlik nihayet müteaddit milletler arasında harp haline inkılâp etmiş ve böylece harp sahasına ve harp tehlikesine yakın ve hatta uzak memleketler fevkalade ahval ve şartlar içinde kalmışlardır. Bu ahval, bilhassa süratli seyri sebebiyle, hemen her tarafta hükümetlerce alınan fevkalade tedbirlerle karşılanmaktadır. Muhtelif memleketlerde hükümetlere bu hususta verilen geniş salahiyetler zikredilen ahvali en iyi ifade eyleyen alametlerdir. Memleketimizin halen Avrupa'da hüküm süren harbin dışında bulunduğu malumdur. Bununla beraber milli hayatımızda bu istisnai ahvalin tesirlerini önlemek ve sair bakımlardan olduğu kadar, iktisadi bakımdan da tahaffuzî ve tedafüî tedbirler almak zarureti muvahecesindeyiz." ${ }^{2}$ Savaş yılları boyunca alınacak tedbirler bu kanuna dayandırılmıştır. MKK, 26.01.1940 tarihinde yayınlanarak yürürlüğe girmiş, daha sonra çeşitli tarihlerde değişikliğe uğrayarak, Demokrat Parti Döneminde de uygulanmış, Bakanlar Kurulu'nun 16.09.1960 tarihli 5/322 sayılı kararnamesi ile yürürlükten kaldırılmıştır. ${ }^{3}$ Temel gida maddeleri ve temini ile ilgili alınan kararlar, genellikle kanunun 21. ve 22. maddelerine dayandırılmıştır.

Çalışmamızın amacı, 1939-1946 yılları arasında dönem hükümetlerinin temel gida maddelerinin temini konusunda aldığg kararları incelemek olduğu için, hükümetlerin aldığı kararları oluşturan belgelerden hareket edilmiş,

${ }^{2}$ Ahmet Makal, “65.Yılında Koruma Kanunu Çalışma İlişkileri ve İş Mükellefiyeti”, Ankara Üniversitesi Siyasal Bilgiler Fakültesi Gelişme ve Toplum Araştırmaları Merkezi Tartışma Metinleri No: 76, Ankara 2004. T.B.M.M. Zabıt Ceridesi, Devre VI, İçtima: I, Cilt: 8, S: 64, s. 1.

${ }^{3}$ Makal, a.g.m., s.1. 
aynı zamanda dönemin siyasal ve ekonomik durumuna değinilerek alınan kararların kapsamı da incelenmiştir. Hükümetlerin aldığı kararların gerekçeleri, uygulanışı ve hangi kurum ve kuruluşları kapsadığına ilişkin bilgiler ele alınmıştır. Belgeler, Bakanlar Kurulu Kararları, Ticaret, Milli Savunma, İçişleri Bakanlıklarının genelgeleri ile valiliklerin ilgili bakanlıklara yazılarını kapsamaktadır. Alınan kararlara vatandaşın tepkisi ya da yakınmasına, belgelere yansıdığı ölçüde değinilmiştir. Böylece devletin hangi kararları aldığı, beklenti ve hedeflerinin ne olduğu ortaya konulmuştur.

\section{1. ÜLKENİN İÇİNDE BULUNDUĞU SIYYASî VE EKONOMİK}

\section{DURUM}

Atatürk'ün vefatından sonra Cumhurbaşkanlığına oybirliği ile seçilen İsmet İnönü (11 Kasım 1938) Celal Bayar'dan hükümeti yeniden kurmasını istemiştir. ${ }^{4}$ Celal Bayar'ın 11 Kasım 1938'de kurduğu hükümet 25 Ocak 1939'a kadar kısa bir süre görev yapmış, yerini aynı tarihte kurulan ve hükümette İçişleri Bakanlığı'nda bulunan Refik Saydam Hükümeti'ne bırakmıştır.

Refik Saydam Hükümeti'nde İçişleri Bakanı Faik Öztrak, Adalet Bakanı Tevfik Fikret Sılay, Milli Savunma Bakanı Naci Tınaz, Dışişleri Bakanı Mehmet Şükrü Saraçoğlu, Maliye Bakanı Fuat Ağralı, Bayındırlık Bakanı Ali Çetinkaya, Milli Eğitim Bakanı Hasan Âli Yücel, İktisat Bakanı Hüseyin Hüsnü Çakır, Sağlık Bakanı Ahmet Hulusi Alataş, Gümrük ve Tekel Bakanı Ali Rana Tarhan, Ziraat Bakanı Muhlis Erkmen görev almışlardır. ${ }^{5}$ Celal Bayar Hükümeti'nde görev alan bakanlardan on kişi Saydam Hükümetinde yer almıştır.

Cumhurbaşkanı İnönü, Cumhuriyet Halk Partisi'nin Büyük Kurultayı'nda 26 Aralık 1938'de değişmez genel başkan ve aynı zamanda Milli Şef olarak seçilmiştir. Bu uygulamayla, Atatürk'ün vefatından sonra meydana gelen boşluk milli şeflikle doldurulmaya çalış1ırken, bütün dünyaya Türkiye'de bir otorite boşluğunun olmadığı anlatılmak isteniyordu. Ayrıca, o dönemde İtalya, Almanya, İspanya, Sovyetler Birliği gibi ülkelerde tek lider söz sahibi idi. Yaklaşan İkinci Dünya Savaşı yıllarında Türkiye’nin

\footnotetext{
${ }^{4}$ Celal Bayar yeni hükümeti kurarken, önceki hükümetlerde görev alan Dâhiliye Vekili Şükrü Kaya ile Hariciye Vekili Tevfik Rüştü Aras, İsmet İnönü'nün isteği ile yeni hükümette yer almamıştır. Bkz. Cemil Koçak, "Siyasal Tarih 1923-1950”, Çağdaş Türkiye 1908-1980, Editör: Sina Akşin, Cem Yayınları, İstanbul, 1995, s.123.

${ }^{5}$ www. tbmm.gov.tr/Hükümetler/ HB11.htm, Erişim Tarihi 24.01.2010.
} 
bir lider etrafında toplanmış, birlik ve beraberlik içinde olan bir ülke görüntüsü vermesi gerektiği düşüncesi paylaşıllyordu. ${ }^{6}$

İsmet İnönü Cumhurbaşkanı olduktan sonra 26 Mart 1939'da seçimlere gidilmiş; Türkiye Büyük Millet Meclisi üyeleri yenilenmiştir. Meclise 424 milletvekili seçilirken, Kazım Karabekir ve Kazım Orbay gibi Atatürk Dönemi'nde meclis dışında kalan kişiler tekrar seçilmişlerdir. ${ }^{7}$ Meclise giren üyelerin 125 'i yeni isimlerden oluşurken, bir kısmı Atatürk döneminin kırgın isimleridir. Ayrıca devrimleri benimseyemeyip yurt dışına gidenler geri dönmeye başlamışlardır. Örneğin, Halide Edip Adıvar 1939 yılı başlarında yurda dönmüş, İngiliz Dili ve Tarihi profesörlüğüne atanmıştır. ${ }^{8}$ İsmet İnönü'nün Cumhurbaşkanı seçilmesiyle, Milli Şef olarak nitelendirilmesi, hükümetin ve devamında seçimlerin yenilenmesi, önceki dönemin kırgın isimlerinin siyaset sahnesinde yerini alması, Dışişleri, İçişleri ve Milli Eğitim Bakanlıklarına yeni isimlerin getirilmesi, Mecliste bir Müstakil Grup oluşturulması “İnönü Dönemi”nde kimi farklılıkların olacağının işaretini vermiștir.

Dış politikada ise gelişmelere bağlı olarak temkinli bir siyaset izlenirken, Atatürk döneminin sınırlarını güvence altında tutma kaygısını ön plana alan, bölgesel ittifakların dışına çıkılarak özellikle Balkanlarda meydana gelen gelişmeler 1şığında farklı ittifak arayışlarına gidilmiştir. İtalya'nın 1939 yılında Arnavutluk'u işgal etmesi Türkiye'yi dış politikada farklı arayışlara itmiş, 12 Mayıs 1939'da İngiltere, 23 Haziran 1939'da ise Fransa ile Barış Cephesi Deklârasyonu yayınlanmış, 19 Ekim 1939'da Türk Ingiliz- Fransız Itttifak Antlaşması imzalamıştır. ${ }^{9} \mathrm{Bu}$ anlaşmanın Sovyetler Birliği tarafından olumsuz karşılanmaması için çaba harcanırken Sovyetler Birliği devlet adamları Türk Dışş̧leri tarafından bilgilendirilmiştir. Türkİngiliz anlaşması Almanya ve İtalya'yı rahatsız ederken Türkiye-İngiltere yakınlaşmasından kaygılanmalarına rağmen Almanya Sovyetler Birliği ile anlaşmaya önem vererek yakınlaşmanın üzerinde çok durmamıştır. ${ }^{10}$ Cüneyt

\footnotetext{
${ }^{6}$ Çetin Yetkin, Türkiye'de Tek Parti Yönetimi 1930-1945, Altın Kitaplar Yayınevi, Birinci Bask1, İstanbul, 1983, s. 159.

${ }^{7}$ Hakkı Uyar; "Tek Parti Döneminde Seçimler", Toplumsal Tarih Dergisi, İstanbul, Nisan 1999, s. 21.31 .

${ }^{8}$ Yetkin; a.g.e. s. 177

9 Mehmet Gönlübol, Olaylarla Türk Dış Politikası 1919-1990, Siyasal Kitabevi, Ankara 1993, s.141.

${ }^{10}$ Hitler'in Türkiye'ye fazla önem vermediğini şu satırlardan anlamak mümkündür. Alman generalleri ile 22 Ağustos'ta yaptığı toplantıda “Küçük devletlerden korkmuyorum. Türkiye'yi Kemal'in ölümünden sonra budala ve aptallar idare etmektedir" gibi sözler söylemesi ve Alman-Rus saldırmazlık paktı müzakerelerinde Almanya'nın İstanbul ve
} 
Arcayürek, İkinci Dünya Savaşına Ait Gizli Belgeler adlı yazısında savaşın ilerleyen aşamalarında Hitlerin ordusuna, Türkiye'ye 7 Mart 1941'de saldırı emrini verdiğini yazmaktadır. ${ }^{11}$ Yazar görüşünü: "Savaşın doğrudan tarafı olan ülkelerin baskısını savaş boyunca hisseden Türkiye'nin politikasının savaşa katılmamak olduğunu belirtmeliyiz" şeklinde ifade etmiştir.

İkinci Dünya Savaşı'nın başlarında, savaştan hangi devletin galip çıkacağı konusu dönemin gazetelerinde dış politika yazarlarının yazı konusu olmuş, hatta bu konuya ilişkin yazılardan ötürü gazetelerin kapatıldı̆̆ 1 olmuştur $^{12}$. Genel olarak İnönü dönemi diye nitelendirilen 1939-1949 tarihleri arasında İkinci Dünya Savaşı yıllarında basına getirilen sansür diğer yıllara göre daha fazladır. Yayın yasağında öne sürülen sebepler "dost bir ülke aleyhine yazılan yazılar", ya da "Türkiye'nin çıkarlarına aykırı yapılan yayınlar" başlığı altındadır ${ }^{13}$. $\mathrm{Bu}$ dönemde dış politika aleyhine yazılan yazılardan ötürü yedi defa yayın yasağı getirildiği görülmektedir. ${ }^{14}$

Cumhurbaşkanı İnönü’nün, TBMM açış konuşmalarında ve Cumhuriyet Halk Partisi'nin kurultaylarında değindiği temel konular, milli birlik ve beraberlik, yabancı ülkelerle ilişkiler, temel gıda maddelerinin temini ve üretimi ve eğitimdir. İsmet İnönü, savaşın başladığı yıllarda temel gida maddelerinin ülke ihtiyaçlarına yeterli olduğu vurgusunu yaparken savaşın ilerleyen safhalarında, ülkede baş gösteren gıda sıkıntısına karşı alınan önlemlere değinirken karşılaşılan sıkıntıların sebeplerini ve neden olan kişileri doğrudan suçlayıcı konuşmalar yapacaktır. Bu konuşmalara sırası geldikçe makalede yer verilecektir.

1 Eylül 1939'da başlayan savaş bütün dünyada sosyal, ekonomik dengeleri altüst ederken, yalnızca savaşa katılan ülkelerin değil, Türkiye gibi ülkelerin de ekonomik dengesini bozmuştur. Savaşa girmemiş ülkeler de her an savaşa katılacakmış gibi ordusunda asker sayısını arttırmış, silahlı kuvvetlerine daha fazla harcama yapmaya başlamış; "savaş ekonomisi" uygulamaya başlamıştır. ${ }^{15}$

Boğazlara kadar Balkanlar'da bir siyasal çıkarı bulunmadığını belirtip, Rusya'yı bu bölgede serbest birakması bunu göstermektedir, a.g.e., s.140.

${ }^{11}$ Doğan Avcioğlu, Milli Kurtuluş Tarihi, Cilt:4, Tekin Yayınevi, İstanbul, 1996, s. 1521.

${ }^{12}$ Nadir Nadi, Perde Aralığından, Çağdaş Yayınları, İstanbul, 1991, s. 131.

${ }^{13}$ Mustafa Yılmaz, Yasemin Doğaner, Cumhuriyet Döneminde Sansür, Siyasal Kitabevi, Ankara, 2007, s. 128.

${ }_{15}^{14}$ A.g.e., s. 18.

15 Şevket Süreyya Aydemir "savaş ekonomisi” kavramının topyekûn savaş anlayışından geldiğini söyler. Topyekûn savaş anlayışı ise Birinci Dünya Savaşı'ndan gelmektedir. Savaşın topyekûn niteliği üzerine ilk defa dikkati çeken General Lüdendorf'tur. Yazar General'den yaptığı alıntıyla kavramı açıklar. 
"Savaş ekonomisi" deyimi ekonomik ihtiyaçların ve koşulların savaş durumu gözeterek belirlenmesi ve yönlendirilmesidir. Savaş ekonomisi uygulayan ülkeler para, kredi, ulaştırma ve endüstri faaliyetlerini bu çerçeve içinde düzenleme yoluna gitmişlerdir. ${ }^{16}$ Birçok ülke savaş başlamadan önce hazırlıklarını bu yönde gerçekleştirirken, Türkiye'nin bu hazırlıkları gerçekleştiremediği görülmüştür. Atatürk, savaşın yakında çıkacağını tahmin ederken, üzüldüğü husus, bu savaş esnasında kendisinin hasta yatağında olacağı düşüncesidir. Sınıf arkadaşı ve silah arkadaşı Ali Fuat Cebesoy'un bu konudaki anısı şöyledir:

"Fuat Paşa, pek yakında dünya vaziyeti mütareke senelerinden daha ciddi olacak ve karışacaktır. İkinci bir harp karşısında kalacağız. Dünyaya hâkim olan milletleri idare edenlerin arasında maatteessüf birinci derece devlet adamı çıkmıyor. (Hitler ve Mussolini'yi kasderek) Avrupa'da birkaç maceraperest Almanya ve İtalya'nın başında cebren bulunuyorlar. Karşı karşıya geldikleri zayıf devlet adamlarının aczinden cüret alıyorlar. Bunlar bugün dünyayı kana boyamaktan çekinmeyeceklerdir. Eski dostumuz Rus Sovyet Hükümeti acizlerle maceraperestlerin yanlış hareketlerinden istifa etmesini bilecektir. Bunun neticesinde dünyanın vaziyeti ve muvazenesi kâmilen değişecektir. İşte bu devre esnasında doğru hareket etmesini bilmeyip en küçük bir hata yapmamız halinde başımıza mütareke senelerinden daha çok felaketler gelmesi mümkündür... ${ }^{17}$

Ali Fuat Paşa'nın Atatürk'ten aktardığı bu anı, konumuz açısından birden fazla anlam taşımaktadır. Her şeyden önce Hitler'i ve Mussolini'yi değerlendirmesi, savaşın sonuçları açısından baktığımızda isabetli bir analizdir. Yine savaştan sonra ABD ve Sovyetler Birliği'nin güçlü iki devlet olarak çıkması, Atatürk'ün dünyanın içinde bulunduğu durumu ve bu durumun yaratacağ1 sonuçları sezgi gücünün ötesinde son derece gerçekçi tespitlerde bulunduğunu göstermektedir. Hitler'in Atatürk'ten sonra

\footnotetext{
“ Bu savaşta artık ordu ve donanma kuvvetinin nerede başladığl, millet kuvvetinin nerede bittiği ayırt edilemiyordu. Ordu ve millet birbirine karışmıştı. Dünya kelimenin tam manasıyla milli bir savaş karşısındaydı."

Aydemir, İkinci Dünya Savaşı başladığında Türkiye'nin böyle bir hazırlığı olmadığ1 gibi, böyle bir görüşün, anlayışın ve örgütlenmenin de olmadığını yazmaktadır. Devamında Türk Savunma Sisteminin tamamen demode ve hazırlıksız olduğu görüşünü ileri sürmüştür. Sonuçta ordu ve halk açısından iaşe sorununun ortaya çıkmasına neden olduğu yazmıştır. Aydemir, İkinci Adam, Remzi Kitabevi, C: II, İstanbul, 1991, s. 207, 208.

${ }^{16}$ Kemal Arı, Ikinci Dünya Harbi ve Türkiye, Genelkurmay Askerî Tarih ve Stratejik Etüt Başkanlığ Yayınları, Ankara, 1998, s.447

17 Ali Fuat Cebesoy, Siyasi Hatıralar, II. Kısım, Doğan Kardeş Yayınları, İstanbul, 1960, s.252.
} 
Türkiye'yi yönetenler hakkında saygısızca değerlendirmelerde bulunmasına rağmen, Atatürk'ü ne kadar önemsediğini de gösteriyor.

Ali Fuat Paşa, Atatürk ile olan görüşmesini naklederken devamında tıpkı Milli Mücadele'de olduğu gibi kendisinin ve diğer silah arkadaşlarının emrinde birleşeceklerini söylediğinde Atatürk'ün yüzünde memnuniyet belirtileri olduğunu nakletmektedir ${ }^{18}$. Atatürk'ün ömrü savaş1 görmeye yetmemiştir ama, ülkenin yönetimini eline alan İsmet İnönü'nün Milli Mücadele'de etkin olan isimleri tekrar meclise taşıdığ 1 ve dönemin hükümetlerinde görevlendirdiği düşünüldüğünde Atatürk'ün düşündüğü doğrultuda siyaset izlediği yanlış bir tespit olmayacaktır.

\section{2. İKİNCİ DÜNYA SAVAŞI'NDAN ÖNCE ALINAN TEDBİRLER}

Türkiye Kurtuluş Savaşı'nı başardıktan sonra topyekûn bir ekonomik kalkınma hamlesi başlatmış, İkinci Dünya Savaşı yıllarına gelinceye kadar, tarımda ticarette, sanayide üretim kapasitesini arttırırken, milli ekonomisini eskisine göre güçlendirmiştir. 17 Şubat 1923 'te İzmir'de İktisat Kongresi düzenleyerek bir anlamda ekonomide izleyeceği yolu belirlemesine rağmen yönetim 1930'a kadar köklü reformlar gerçekleştirmiş, fakat ekonomide istediği gelişmeyi sağlayamamıştır. Öte yandan Lozan Antlaşması'nda belirlenen diş borçların düzenli olarak ödenmesi de bir takvime bağlanamamıştır.

1929'da ortaya çıkan dünya ekonomik bunalımı, Türkiye'nin dış satımını engellerken zayıf olan ekonomisini yeni çıkmazlara sürüklemiş, çıkış yolları arayan yönetim bir çare olarak yeni bir siyasal parti kurulmasına başvurmuş̧tur. Bu amaçla Fethi Okyar'ın başkanlığında 12 Ağustos 1930'da Serbest Cumhuriyet Fırkası adıyla ekonomide serbestliği savunan bir parti kurulmasına rağmen beklentilere yanıt veremediğinden 16 Kasım 1930'da kendini feshederek deneme sona erdirilmiştir. ${ }^{19}$ Tek parti iktidarı ülkeyi yönetmeye devam ederken 1935 'te ise parti ile devlet birleştirilerek resmi olarak tek partili devlet sistemine geçilmiştir. ${ }^{20}$

Kısa bir süre içinde ekonomiye yön ve şekil verecek olan Kamu İktisadi Teşekkülleri oluşturulmaya başlanmıştır. Örneğin; 3 Haziran 1933 tarihinde Sümerbank, Halk Bankası, Halk Sandıkları, Türk Hava Yolları İdaresi,

18 A.g.e., s.253., Bkz. Şevket Süreyya Aydemir, Tek Adam Mustafa Kemal, Cilt 3, Remzi Kitabevi, İstanbul, 1995. s. 555-556.

19 Bkz. Ahmet Ağaoğlu, Serbest Fırka Hatıraları, İletişim Yayınları, İstanbul, 1982, s.166; Cetin Yetkin, Serbest Cumhuriyet Firkası Olayl, Karacan Yayınları, İstanbul, 1982, s.30. Kandemir, Siyasi Dargınlıklar: Serbest Firka Nasıl Kuruldu Nasıl Kapatıldı?, Ekincigil Matbaas1, İstanbul, 1955, s. 3-128.

${ }^{20}$ Yetkin, a.g.e., s. 128. 
Belediyeler Bankası, Eskișehir Şeker Fabrikası kurulmuștur. 1934'te Turhal Şeker Fabrikası, krom yatakları, Bakırköy Feshane Yünlü, Hereke İpekli ve Yünlü Dokuma Fabrikaları, Beykoz Deri ve Kundura fabrikaları Sümerbank'a devredilmiştir. 1935'te Maden Tetkik Arama Enstitüsü, Elektrik Etüt İdaresi kurulurken, madencilik ve enerji alanındaki kuruluşlar devletleştirilmiş, yabancı şirketler millileştirilmiştir. Yeni iplik ve dokuma fabrikalarının temeli atılmış, şeker fabrikaları Türkiye Şeker Fabrikaları Anonim Şirketleri adı altında birleştirilmiştir. 1936'da kâğıt, dokuma, kömür ve madenlerle ilgili yatırımlar yapılarak üretimine başlanmıştır ${ }^{21}$.

Tek Parti Dönemi’nde planlı kalkınma dönemine geçilerek, beş yıllık kalkınma planları çerçevesinde yatırımlar yapılmıștır. Savaş yıllarında önemli fonksiyonları yerine getiren Toprak Mahsulleri Ofisi ${ }^{22} 1938$ 'de kurulmuştur. Savaşın başlamasılyla birlikte savaş boyunca tahıl üretiminde düşüşler olmuştur. Konumuz açısından savaş yılları boyunca eksikliği hissedildiği için tüketimi konusunda sık sık düzenlemelere gidilen başlıca ürünlerin üretimi aşağıda verilmiştir.

\begin{tabular}{|c|c|c|c|}
\hline$\underline{\text { Yillar }}$ & Buğday /ton & Arpa /ton & Misir/ton \\
\hline 1939 & 4.191 .528 & 2.275 .460 & 635.855 \\
\hline 1940 & 4.067 .950 & 2.249 .314 & 757.309 \\
\hline 1941 & 3.483 .147 & 1.758 .246 & 647.467 \\
\hline 1942 & 4.263 .282 & 2.164 .781 & 852.828 \\
\hline 1943 & 3.509 .507 & 1.665 .322 & 874.265 \\
\hline 1944 & 3.148 .396 & 1.403 .049 & 508.296 \\
\hline 1945 & 2.189 .318 & 934.309 & 294.739 \\
\hline 1946 & 3.648 .383 & 1.653 .592 & 594.838 \\
\hline 1947 & 3.245 .904 & 1.511 .752 & 530.790 \\
\hline & 4.867 .093 & 2.167 .396 & 695.651 \\
\hline
\end{tabular}

Tablo: Türkiye İstatistik Kurumu İstatistik göstergeler 1923-2008

Tahıl üretimi 1942 yılının dişında savaş öncesi üretim miktarına ulaşamazken, buğday ve arpa üretimindeki savaş öncesindeki miktara ancak 1948 yılında ulaşılabilmiştir. Türkiye'de toplam nüfus, 1940 nüfus sayımına

\footnotetext{
${ }^{21}$ İhsan Keser, Türkiye'de Siyaset ve Devletçilik, Gündoğan Yayınları, Ankara, 1993, s. 100 101.

${ }^{22}$ A.g.e., s. 101

${ }^{23}$ www. tuik.gov.tr/y1llı//̇sst_gostergeler.pdf, Erişim Tarihi 28.01.2010.
} 
göre 17.820.950, 1945 yılındaki nüfusu ise 18.790 .174 'tür ${ }^{24}$. Diğer dönemlerdeki beş yıllık nüfus artış miktarına baktığımızda savaş yıllarında nüfus artış oranı düşük olmasına rağmen temel besin maddelerinde de üretimde düșüş söz konusudur. Bu düșüș ayrıca temel gida maddelerinin fiyatlarının artmasının nedenlerinden biri olmuştur. Fiyat artışının önüne geçmek için Ticaret Bakanlığı'nda bir "Hayat Pahalılığıyla Mücadele Servisi" kurulmuştur. Fakat kurulan bölüm fiyat artışlarının önüne geçememiştir. Üretici durumunda olan köylüler zarara daha çok maruz kalmıştır. Köylü nüfusu o dönemde ülke nüfusunun $\% 75$ 'ini oluşturmaktadır. Hükümet fiyatları düşük tutmak isterken gerek vergilerin ağırlığı, gerekse iklime bağlı üretim düşüklüğü, üretici köylüleri adeta sefalete sürüklenmiştir. Ürünlerin maliyeti artmış, üreticilerin düşük olan kârları daha aşağılara inmiștir. Toprak Mahsulleri Ofisi kurulduktan sonra üreticiye $\% 5^{\prime}$ lik bir kâr oranı tanımış ${ }^{25}$, maliyetlerin yükselmesi sonucunda kâr bir yana zarar etmişlerdir. Savaş boyunca Türkiye'de fiyat artışı ortalama $\% 43$ olurken, 1939'dan 1948'e kadar yıllık ortalama fiyat artışı \% 48 olmuştur. ${ }^{26}$

Savaş başladıktan sonra "Müdafaa Ekonomisi" adı altında bir milli savunma raporu hazırlanarak, ülkenin barışta ve savaşta gücünün ne oranda olduğu tespit edilmeye çalış1lmıştır. Hükümet her alanda kontrolünü sıkılaştırarak alınacak tedbirleri ele almıştır. Bir seferberlik şeması hazırlayarak, sınaî, zirai, ulaștırma, ticarî, malî seferberlik başlıkları altında çalışmalar yapmıştır. ${ }^{27}$

Avrupa'da savaşın başlaması, Türkiye'de etkisini ihracat ve ithalat rakamlarında da göstermiştir. Savaş yıllarında hem ihracatta hem ithalatta düşüş olmasına rağmen, ihracatın ithalatı karşılama oranında yükseliş olmuştur. $^{28}$

$\begin{array}{llll}\underline{\text { Y1llar }} & \underline{\text { Ithalat } \$} & \underline{\underline{\text { Ihracat } \$}} & \text { Dolar kuru Tl/\$ } \\ 1939 & 92.498 & 99.647 & 1,28 \\ 1940 & 50.035 & 80.904 & 1,38 \\ 1941 & 55.349 & 91.056 & 1,35 \\ 1942 & 112.879 & 126.115 & 1,31\end{array}$

${ }^{24}$ www. tuik.gov.tr/y1llık/İst_gostergeler.pdf, Erişim Tarihi 28.01.2010.

${ }^{25}$ Aydemir, s.209.

${ }^{26}$ Keser, a.g.e., s. 102.

${ }^{27}$ A.g.e., s. 212.

${ }^{28}$ www.tuik.gov. tr, 28.01.2010. Devlet İstatistik Enstitüsü fiyat tutarlarını dolar olarak verdiği için değiştirmeden biz de dolar olarak verdik. Sayıların milyon olarak okunması gerekir. 


$\begin{array}{lrll}1943 & 155.340 & 196.734 & 1,31 \\ 1944 & 126.230 & 177.952 & 1,31 \\ 1945 & 96.969 & 168.264 & 1,30 \\ 1946 & 118.889 & 214.580 & 2,01 \\ 1947 & 244.644 & 223.301 & 2.80\end{array}$

Tablo: Türkiye İstatistik Kurumu İstatistik Göstergeler 1923-2008

İhraç mallarının genelde tarım ürünleri ve maden gibi hammaddelere dayandığı için, içeride tarım ürünlerine yoğun ihtiyaç olmasından dolayı tarım ürünleri oranı da savaş öncesi döneme göre düşmüştür. Maden ihracatında ise özellikle Almanya'ya ihracat miktarı ve değeri artmıştır. İthalatın payının savaş döneminde düşük olmasının önemli nedenlerinden biri, savaştan önce ithalat yaptığı ülkelerinin büyük çoğunluğunun savaşa katılması nedeniyle miktar olarak ve değer olarak azalma olmasıdır. Ayrıca savaştan önce başlatılan planlı kalkınma politikası terk edilmiştir. Planlı kalkınmadan vazgeçilmesinin önemli nedenlerinden biri, ihtiyaç duyulan maddelerin ülkeye getirilmesindeki zorluk olarak değerlendirilmiştir. Bir diğer nokta ise hem ihracatta hem ithalatta Türkiye, Almanya'ya büyük oranda bağımlı kalmıştır. Savaş boyunca döviz ve altın rezervlerinde birikme olmasına rağmen savaş ekonomisi koşullarından dolayı bu birikimleri yatırıma dönüştürememiştir. ${ }^{29}$ Nüfus bu dönemde yavaş artmasına rağmen, kişi başına düşen milli gelir azalmış, yukarıdaki tabloda da görüldüğü gibi, Türk parası Amerikan Doları karşında iki kat değer yitirmiştir. ${ }^{30}$

Refik Saydam Hükümeti döneminde (1939-1942) tarım ürünleri piyasa fiyatlarının altında satın alınarak özellikle kentli nüfusa ucuza dağıtılma yoluna gidilirken, dokuma ürünlerine gıda maddelerinde izlenen sık1 fiyat politikasına gidilmemiștir. Ne var ki dokumanın hammaddesini olușturan pamukta ise sık1 fiyat politikası uygulandığ 1 için pamuğu üreten çiftçiden ucuza pamuk alınmış, kârı devlet ve tüccar yapmıştır. Zira devletin ve özel kesimin elinde olan dokuma ve iplik fabrikaları kâr yapmışlardır. Keza şeker satışından da devlet yüksek kârlar elde etmiştir ${ }^{31}$.

İsmet İnönü dönemi olarak adlandırılan bu yıllarda, Türkiye savaş dışında kalmakla birlikte halk büyük sıkıntılar çekmiş, yoksulluğun

\footnotetext{
${ }^{29}$ Keser, s. 103.

30 Agah Oktay Güner, Türkiye’nin Kalkınması ve İktisadi Devlet Teşekkülleri, Damla Yayınevi, İstanbul 1978, s.45-54.

${ }^{31}$ Korkut Boratav, Türkiye'de Devletçilik, Savaş Yayınları, Ankara 1982, s.221.
} 
pençesine düșen halk temel gereksinimlerini karșılamakta zorlanmıștır. Savaş boyunca iki milyona yakın erkek nüfusu silâhaltına alınırken, ordunun gereksinimlerini karşılamaya öncelik verilmiştir ${ }^{32}$. Diğer yandan silâhaltına alınan insanlar toplumun en üretken kesimini oluşturduğundan ülke, üretim kaybı ve işgücü kaybına uğramıştır. Weisband'da göre, İsmet İnönü savaş boyunca ağırlığı dış politikaya vererek iç politikada hükümeti uygulamalarında serbest bırakmıştır. Yazar, İnönü'nün izlediği bu yolun gerekçesini, asker olması ve karakter olarak ölçülü bir kişiliğe sahip olmasına bağlamıştır. Yazar, İsmet İnönü'nün kişiliğinde Türkiye'nin dış politikasının şekillendiği değerlendirmesini yaparak; Türkiye savaşa girmeye her an hazır olduğunu, fakat İsmet İnönü'nün koyduğu şartların gerçekleşmesi koşuluna işaret etmiştir. İsmet İnönü’nün, aceleci ve atak bir politikanın Türkiye'yi ateşe atacağının bilincinde olduğu görüşündedir. Böylece İnönü, savaşa girmemekle ülkeyi büyük bir felaketten kurtardığına hep inanmıştır. ${ }^{33}$ Abdi İpekçi ile yaptığ 1 bir söyleşide İnönü, "Harbe girmek ihtimali olursa bir gün sonrası kârdır. Hatırınızda olsun hiçbir vesileyle önce davranmaya heves etmeyin" ${ }^{34}$ diyerek savaş zamanındaki tutumu, onun politikasını değerlendiren kişileri yanıltmamıştır.

\section{SAVAŞ DÖNEMINDE ALINAN KARARLAR}

\subsection{Ordunun İhtiyacını Gidermede Karşılaşılan Sıkıntılar ve}

\section{Tedbirler}

Savaşın başlayacağı belli olduktan sonra hükümet, temel ihtiyaç maddelerinin en önemlisi olan buğday konusunda tedbirler almaya başlamıştır. Bakanlar Kurulu, devletin gıda ihtiyaçlarını karşılamakla yükümlü olduğu ordu, okul ve diğer resmi dairelerin buğday ihtiyaçlarını Toprak Mahsulleri Ofisi tarafindan kâr yapmadan adi geçen kurumlara vereceğini ilan etmiştir. ${ }^{35}$

Milli Müdafaa Vekâleti 7.12.1939'da 12830 sayılı genelge ile ordunun ihtiyacı olan buğday ve unu ne şekilde temin edeceğini belirtmiştir. Genelgede ayrılan bütçenin en tasarruflu şekilde kullanılabilmesi için çözüm

\footnotetext{
${ }^{32}$ Suna Kili, Türk Devrim Tarihi, Türkiye İş Bankası Kültür Yayınları, İstanbul 2000, s.249.

${ }^{33}$ Edvard Weisband, İkinci Dünya Savaşı'nda İnönü'nün Dış Politikası, Cumhuriyet, Çağdaş Matbaac1l1k, İstanbul 2000, s.21-22.

${ }_{34}^{34}$ Abdi İpekçi, “İnönü Dünya Savaş1 Anılanı Anlattı”, Milliyet, 06.05.1973, s. 1. 9.

35 Başbakanlık Cumhuriyet Arşivi; 030.18. 01.02/ 85.118.16. Takip eden dipnotlarda Başbakanlık Cumhuriyet Arşivi BCA biçiminde kısaltılarak yazılacaktır.

Toprak Mahsulleri Ofisi Kanunu 24.06.1938'’de 3491 Sayılı Kanun olarak çıkmıştır. Resmî kurumların buğday, un, arpa, yulaf gibi ihtiyaçlarının karşılanması, Kanunun 21. maddesinde tanımlanmıştır.
} 
arandığ görülmektedir. Merkezden uzakta olan ordu birliklerinin buğday ve un ihtiyaçlarını karşılamaları için bedeli Toprak Mahsulleri Ofisi bütçesinden olmak üzere bulundukları mahalde ofis temsilciliklerinden buğday olarak temin etmeleri ve o çevrede bulunan değirmenlerde öğütmeleri istenmiştir. ${ }^{36}$ Yayınlanan genelge ile ordunun temel ihtiyacı olan ekmek ve orduda bulunan hayvanların yem ihtiyacını en kısa sürede karşılanması amaçlanmış, günün koşullarında merkezden uzak yerlerdeki birliklerin ihtiyaçlarının giderilmesinde doğabilecek gecikmenin önüne geçmek istenmiştir.

Ordunun buğday ve un gibi ihtiyaçları Toprak Mahsulleri Ofisi tarafından karşılanırken arpa ve yulaf hayvan yemleri ihtiyacının önemli miktarlara ulaşması sonucunda, bu maddelerin de temini 07.10.1939 tarihli ve 12234 sayılı karar ile Ofise verilmiştir. Sadece batıdaki askeri birliklerde hayvan mevcudu sayısının yüz bin olması yem ihtiyacının miktarını aylık on beş bin tona çıkarmıştır. 1940 yılı itibariyle ne Ofisin elinde bu kadar yem mevcuttur, ne de askeri birliklerde istenen miktarda yem bulunmaktadır. Ülkede bulunan şahıs ve tüzel kişiliği olanlardan ellerinde ihtiyaç fazlası bulunan yemlik mahsulün Toprak Mahsulleri Ofisine satmaları hükümet tarafindan istenmiş, fakat ihtiyaç duyulan miktar elde edilememiştir. Sebebine gelince; İhracatçı Birliği'nin elinde 6600 ton arpa ve yulaf bulunmasına rağmen ofisin tüccarlardan mahsul satın alması yasaktır ve önemli miktardaki yem stoku satın alınamamıştır. Diğer yandan, bahsedilen stok sadece bir merkezde değildir. Yurdun çeşitli bölgelerinde yedi merkezde bulunan mahsulün toplanması nakliyat sorunu doğurmuştur. Öte yandan tüccarlar köylünün elindeki mahsulü ofisin satın aldığı fiyattan daha yüksek fiyat vererek üreticilerden satın almaktadır. Böylece tüccarlar piyasada bulunan mahsulleri toplayarak devleti kendilerinden daha pahaliya mal almaya mecbur etmek istemişlerdir. Hükümetin karşı tedbiri ise Trakya bölgesinde askeri kolordu komutanlıkları tarafından sınırdan başlamak üzere günlük ihtiyaç için kendilerinin üreticiden mahsul satın almak olmuştur. Doğu bölgesindeki askeri birliklerin durumlarının farklı olmadığını, şartların daha elverişsiz olduğunu bildirilmektedir. İhtiyacın karşılanabilmesi için Devlet Demiryollarından tren tahsis edilmesine rağmen bir ay zarfinda ancak on bin ton mahsulün batıya nakledilebileceği, geriye kalan ihtiyacın ordu birlikleri tarafından halktan bizzat alınacağı bilgisi verilmiştir.

Ordunun ekmeklik ihtiyacını karşılamak için buğday stoku da sıkıntılıdır. Milli Savunma Bakanlığı Levazım İşleri Daire Başkanlığı karşı karşıya kalınan sıkıntılı durumu, ihtiyaçların sorunsuz bir şekilde

${ }^{36}$ BCA:030.10.01.02/ 50.322. 12. 
karşılanması gereğini bir rapor haline getirerek Başbakanlığa ve Ticaret Bakanlığına bildirmiştir. Çözüm önerisi olarak Toprak Mahsulleri Ofisi'nin aynı sıkıntı ile karşılaşmaması için en az üç aylık stok biriktirmesi gerektiğini raporda işaret etmiştir. ${ }^{37}$

\subsection{Ekmek Üretimi ve Dağıtımı İçin Alınan Tedbirler}

Buğday sıkıntısının ülkenin her köşesinde hissedilmeye başlanmasıyla birlikte hükümetin aldığı önlemlerden birisi de vilayetlerde ekmeğin üretim kalitesini kontrol altına almak olmuştur. İçişleri Bakanlığı emri ile valilere birer genelge gönderilerek belediyeler aracıllğıyla ekmeğin randıman ${ }^{38}$ miktarının bütün firınlarda aynı ölçüde olması istenmiştir. 1940'ta \%80 randımanlı ekmek üretilmesi istenmiştir. Örneğin İstanbul'da halka satılan yüzde seksen randımanlı bir ekmeğin dörtte biri ile \%86 randımanlı bir asker tayınının yarım parçası Başbakan'ın kontrolüne sunulmuştur. ${ }^{39}$ Ayrıca Başbakanlık, 1940 Aralık ayında valiliklere bir talimatname göndererek, buğday fiyatlarına gelen zamdan sonra şehir ve kasabalarda ekmeğin kilosunun kaç kuruşa satıldığının acele bildirilmesini istemiştir. ${ }^{40}$ Bütün valiler tespit ettikleri fiyatları, vilayetlerinde üretilen ekmek randıman oranları ile birlikte bir telgrafla bildirmişlerdir. Ankara Valiliği buğdaya yapılan zamdan önce ve zam yapıldıktan sonra bakanlığa, vilayetin ilçeleriyle birlikte ekmek fiyatının örnek tablosunu göndermiştir ${ }^{41}$. Tablonun altındaki açıklama yazısı şöyledir:

"1714 say1lı kararnamenin 4. maddesi mucibince Fiyat murakabe komisyonu tarafından değirmenlerdeki buğday stokları maliyetinin 7.50 kuruş üzerinden tespit edilmesi üzerine Birinci nevi ekmeğin kilosu 13 ve Francalanın 16.75 kuruşa çıkarılmıştır."

Birkaç güne kadar un fabrikalarındaki 7.50 kuruşluk buğday stokunun bitmek üzere bulunması itibarı ile un fabrikalarına buğdaylar 8 kuruştan verildiği takdirde birinci ekmek fiyatı 13.75 , Francala 17.25 , buğday 8.50 den verildiğinde Birinci 14.25, Francala 17.75 üzerinden satılacaktır.

37 BCA: 030.10/50/322/11/24.08.1940.

38 Randıman kelimesinin sözlük anlamı verimdir. Ekmekte ise buğdayın un haline getirilişinde kepeğinin ayrıştırma miktarına denir. Randıman yüzdesi düştükçe buğdayın una dönüşümünde ayrışan maddeler oranı çoğalmakta, randıman yüzdesi yükseldikçe ayrıştırılan madde miktarı azalmaktadır.

39 BCA: 030.10./ 45.290.56/26.10.1940.

${ }^{40}$ BCA: 030.10./184.27.2/ 16.12.1940.

${ }^{41}$ BCA: 030.10./184.271.2/17.12.1940.

BCA: $30.10 / 184.271 / 2$ 
Diğer vilayetlerden gelen telgraflardan anlaşıldığına göre, ekmek ve un fiyatları günün şartlarına göre vilayetin belirlediği değer üzerinden satılmaktadır. Örneğin Çorum vilayetinden gelen telgrafta birinci nevi ekmeğin kilosunun 13 kuruştan, ikinci ve üçüncü nevi mahlût undan yapılan ekmeğin kilosunun dokuz kuruştan satıldığ 1 bildirilmektedir. ${ }^{42}$ Öbür vilayetlerden gelen telgrafların örnekleri aynı olup, vilayetlerdeki buğday fiyatlarına göre farklılıklar vardır.

\section{EKMEKLİK BUĞDAY YETERSIZLİĞİ VE ALINAN TEDBİRLER}

1941 yılına gelindiğinde Toprak Mahsulleri Ofisi ve tüccarın elinde bulunan buğday miktarının halkın tüketimine ve ordunun ihtiyaçlarına yetmeyeceği yapılan araştırmalarda ortaya çıkmıştır. Ticaret Bakanlığı bir takım önlemlere başvurma ihtiyacı duymuştur. Bakanlık, Başbakanlığa sunduğu raporda iki türlü önlem alma niyetindedir. Birinci yol ekmeğin randımanını yükseltmek, ikincisi ise ekmeklik buğdaya çavdar karıştırmaktır.

Hazırlanan raporda hesaplanan ihtiyaç miktarı orduya lazım gelen un miktarı ile 5 milyon kişinin ihtiyacını karşılayacak şekilde belirtilmiştir. Verilen sayıdan anlaşıldığına göre, şehir ve kasabalarda yaşayan halkın ihtiyaçları göz ününe alınarak bu tutar hesaplanmıştır. Ülke nüfusunun 17 milyon civarında olduğu göz önüne alındığında firını olmayan köyler için bir hesap yapılmamıştır. Zira bu tarihlerde fırını olmayan ilçelerin olduğu o dönemde bakanlığa sunulan raporlarda görülmektedir. ${ }^{43}$ Başbakanlığa sunulan raporda ülkenin ihtiyacı ve ofisin elinde bulunan miktar sayılarla izah edildikten sonra sorunun nasıl aşılacağın da açıklaması örneklerle anlatılmıştır. Un randımanının \% 86'ya çıkarılmasıyla \% 9-10 oranında bir tasarruf sağlanacağı, buğdayda bulunan maddelerin yapılan ekmekte daha çok olacağından besin değerinin yükseleceği belirtilmiştir. Ancak ekmeklerin biraz esmerleşeceğini, bunun da bir sorun oluşturmayacağ raporda belirtilmektedir.

Ziraat ve Sağlık Bakanlığı tarafindan oluşturulmuş bir uzman ekip Ankara Mamak'ta bulunan eski tip bir değirmende istenen randımanda un elde ederek bu unlardan Cebeci Halk ve Sebat firınlarında ekmek yaptırılmıştır. Elde edilen ekmek biraz esmer olmuş, öteki ekmeklere göre

42 BCA: 218- Çorum 575 / 17/12-17/ 17.12.1940.

${ }^{43}$ Vilayetlerden gelen ekmek fiyatları listesinde, her vilayet ve kazada kaç tane firın olduğu belirtilirken çeşitli vilayetlerin dört kazasında firın olmadığı yazılmaktadır. BCA: 030.10/184.271.1. 
daha az kabardığı tespit edilmiş; yine de sonuç olumlu bulunmuştur șeklinde rapor edilmiştir. İşaret edilen diğer husus ise bu yolla üretilecek ekmeğin maliyetinin 49 kuruş ucuzlayacağıdır.

Ekmeklik una çavdar katılması hususuna gelince, raporda, ekmeklik una yüzde otuz beş oranında çavdar katılmasının mümkün olduğu belirtilirken, ofisin elinde bu oranda mevcut çavdar stokunun olmamas1, mevcut buğdaylarda yüzde yedi sekiz oranında zaten çavdar olduğu, karıştırılacak miktarın yüzde yedi sekiz olduğu takdirde yüzde on beşe karşıllı geleceği belirtilmiştir. ${ }^{44}$

Ayrıca, alınan önlemler yeterli gelmediğinden Afyon, Konya, Eskişehir, Yozgat, Kırşehir valiliklerine 12 Şubat 1941 'de acele ve gizli bir telgraf çekilerek, üretici ve tüccarın elinde bulunan ihtiyaç fazlası buğday, arpa, çavdar, yulafa el konulması emri verilmiştir. Yollanan emirde ne şekilde el konulacağı belirtilmiştir. İstenilen ihtiyaç fazlası mahsulleri toplamakla görevlendirilen Toprak Mahsulleri Ofisi'nin her şubesi 50 kilometrelik çevreden sorumlu tutulmuştur. Valilerin görevi ise emrindeki memurlar ve jandarma vasitasıyla mahsullerin ofislere aktarılmasını sağlayacaktır. Görevlendirilen memurların ödeneklerinin de vilayetlere gönderileceği yazılmıştır. Elindeki mahsulü teslim eden kişilerin mahsul bedelleri de peşin ödenecektir. Verilen emrin vilayetin genel asayişi ve güvenliği dışında en önemlisi olduğu belirtilmiştir. ${ }^{45}$ Valiliklerin görevlendirdiği memurların hasat zamanı devletin el koyacağı ihtiyaç fazlası ürünleri tespit çalışmaları, özellikle köylülerin mahsullerini saklama çabaları, dönemin hükümet- köylü ilişkisine konu olacak anlatımlara esin kaynağı olmuştur. Örneğin, köylü ile görevli memurların ilişkisi Ali Yüce'nin Şeytanistan isimli romanında şöyle anlatılmıştır $^{46}$ :

"Tahmin memurları tarlalarda dolaşıp tahmin yaptılar. Harman zamanı da ölçüm memuruna da haber vermeden kimse harman savuramıyordu. Dane samandan ayrilınca ölçü memuru ölçüyordu. Tahmin defteriyle karşılaştırıyor. Eksik gelirse tutanak yazıyordu. Ürün sahibi açığı kapatmak için şuradan buradan para ile tahıl satın almak zorunda kalıyordu. Bazen de ölçü memuruna az verip çok yalvararak açığını kapatıyordu. Hükümet payı olarak ayrılan ürünleri köylü atla eşekle sirtıyla kasabaya götürüyordu. Teslim etmek için günlerce süründürülüyor. Aç susuz çamurda soğukta

${ }^{44}$ BCA: $030.10 / 184.272 .1$

${ }^{45}$ BCA: 030.10/ 185.273.5. 12.02.1941. No: 6-249/523

${ }^{46}$ Ali Yüce, "Şeytanistan", Dizi yazı, Milliyet, 01.10.1970, s.4 . Yazı yazarın Köy Enstitüsü yıllarını anlatan romanından alınmış, Milliyet gazetesinde romanın dizi şeklinde yayınından alınmıştır. 
perișan oluyordu. En sonunda gene oradaki memurların gönlünü etmeden, Hacı Mükremin'e boyun bükmeden teslim edemiyorlardı. Teslim makbuzunu eline alıncaya dek, analarından emdikleri burunlarından geliyordu."

Halk arasında ofis memurlarıyla ilgili çeşitli söylentiler dolaşıyordu: "Hökümetin buğdayından elli çuval almışlar, yerine elli çuval kum karıştırmışlar." "Ambardan yüz harar arpa almışlar, yerine yüz harar ufak saman karıştırmışlar."

Anlatılanlar da gösteriyor ki, Ankara'da alınan kararların, uygulayan memurlar ve mahsulüne el konulan köylüler açısından yıllar sonra belleklerinde kalan zor günlerin sıkıntılı yıllarıdır. Aynı zamanda o yıllarda iktidarda olan Cumhuriyet Halk Partisi'ne karşı karşıtlarınca kullanacağı olumsuz icraatlar olarak yansıyacaktır.

Başbakanlık tarafından valiliklere gönderilen emrin aynısı Birinci Umumi Müfettişliğe de gönderilmiştir. Ayrıca Diyarbakır, Afyon, Amasya, Bilecik, Burdur, Çankırı, Çorum, Denizli, Eskişehir, Isparta, Kayseri, Kütahya, Kırşehir, Mardin, Niğde, Urfa Tokat, İstanbul, İzmir, Samsun, Ankara valiliğine gönderilen yazıda ise Ofis tarafından satın alınacak mahsulün bedelinin peşin olarak ödeneceğinin iyi anlatılması gerektiği vurgusu yapılmıştır. $\mathrm{Bu}$ iş için bütün devlet memurlarının görevlendirilebileceği gibi gerektiğinde öğretmen ve eğitmenlerin de görevlendirilmesini istemiştir. Satın alınan mahsullerin en yakın ofis merkezlerine veya demiryolu istasyonlarına en kısa sürede nakledilmesinin önemi vurgulanmıştır. ${ }^{47}$

15224 sayılı Bakanlar Kurulu Kararı'nda tek tip ekmek üretimi ile ilgili Ankara, İstanbul ve İzmir belediyelerince karanın sık1 bir şekilde denetlenmesi istenmiştir. Ekmekler bütün firınlarda \% 85-86 randımanlı çıkacak, karıştırılan çavdar miktarı \% 15'i kesinlikle geçmeyecek, çavdarlar Ofisten temin edilecektir. Ayrıca un imalatını yapan değirmenler sadece izin verilen kendi bölgelerine un ögüteceklerdir. Belediyeler görev alanlarının dışında kalan bir yerden un getiremeyecektir. Francala tipi ekmek üretimi, belediyenin görevlendirdiği fırınların dışında bir yerde üretilmeyecek, belediyenin ihtiyacın dışında fazla üretim yapmayacaktır. Belediyenin belirlediği satış noktaları dışında francala ekmek satışı yasaktır. Ekmek fiyatları 2/14714 numaralı kararnameye uygun şekilde o belediyenin meclisi tarafından belirlenecektir. Üretim ve satış kontrolleri belediyeler tarafından gerçekleştirilmekle birlikte ilgili bakanlıkların görevlendirdiği müfettişler

${ }^{47}$ BCA: 030.10/ 185.273.5 12.02.1941, No: 12098 
tarafindan da gerçekleștirilecektir. Bu kararnamenin yürürlüğe girmesinden itibaren firınlar ellerinde bulundurdukları un miktarını bağlı oldukları belediyelere bildirmekle yükümlüdürler. ${ }^{48}$

Alınan sıkı tedbirlere rağmen ekmeklik buğday yetersizliği daha çok hissedilmeye başlamıştır. Ekmeklik buğday yetersizliğinin önüne geçmek için yukarıda alınan karardan dört ay sonra, Haziran ayında eklemeler yapılmıştır. Bakanlar Kurulu Kararı ile karıştırılacak çavdar miktarının arttırılması istenirken arpa karıştırılmasına da karar verilmiştir. Buğdaya sadece bir maddenin karışımın üst sınırının \% 40 olması kararlaştırılmıştır. Her üç madde karıştırılması durumunda bir maddenin miktarı \%50'yi geçmeyecektir ${ }^{49}$. İstenen karışımları yapmayan kurumlar derhal uyarılarak, müdahale edilmiştir. Örneğin Yalova ve İzmit’te bulunan askerî birliklerde saf buğday unundan ekmek yapıldığı tespit edilerek bizzat Milli Savunma Bakanı bir yazı ile durumu ve alınan önlemi Başbakanlığa bildirmiştir. Toprak Mahsulleri Ofisi'nin Eskişehir şubesinden 5000 çuval arpa unu alınarak birinci ve ikinci ordulara, buğday ununa karıștırılarak üzere gönderildiği bildirilmiştir. Ayrıca İstanbul, İzmir Samsun gibi şehirlerden arpa unu temin edildiği ve birinci ordu emrine teslim edildiği bilgisi verilmiştir. Ordu birliklerinin arpa unu bulamadıkları takdirde en yakın ofis temsilciliklerine müracaat ederek arpa temin etmeleri, bu arpay1 mıntıkalarında değirmenlerde öğüterek karıştırmaları istenmiştir. ${ }^{50}$

Yine aynı yılda yurdun çeşitli yerlerinden gerek bireysel, gerekse kurumsal şikâyetler gelmeye başlamıştır. Mersin'den bir kambiyo memurunun Başbakanlığa çektiği telgrafta belirttiği binlerce insanın ekmek bulamadığı şeklindeki şikâyetini Başbakanlık derhal işleme koymuş, validen bilgi istemiştir ${ }^{51}$. Vali olayı soruşturarak ildeki ekmek üretimi hakkında Başbakanlığa bilgi vermiştir. Şikâyette bulunan kişi ve kişinin komşuları, arkadaşlarından bilgi alınmış, alınan ifadelerde kişinin ve çevresinin ekmeksiz kalmadığı anlaşılmıştır. Fakat İçel iline ekmeklik unun dişarıdan geldiği, zaman zaman gecikmeler yaşandığı, bu nedenle vatandaşların ekmeksiz kalma telaşı ile günlük ihtiyacından fazla iki günlük ekmek aldığı, bu nedenle firınların önünde uzun kuyruklanın oluştuğu, dolayısıyla halkta bir serzeniş olduğunu ifade edilmiştir. Vali, şehirde hiçbir zaman ekmeksiz kalınmadığını bildirmiştir $^{52}$.

${ }^{48}$ BCA: $030.18 .01 / 94.49 .1,18 / 2 / 1941$.

${ }^{49}$ BCA: 030.18.01.02/ 95.49.1, 6.6.1941.

${ }^{50}$ BCA: 030. 10. / 50.323.5/30. 06.1941.

${ }^{51}$ BCA: 030.10/ 65.436.10./ 23.10.1941.

${ }^{52}$ BCA: 030. 10/ 65.436.10/ 29.08.1941. 
Yine İzmir'in Mordoğan Nahiyesi geçici kongre başkanı E. Erol isimli kişinin verilen buğdayın azlığı nedeniyle ilçelerinde açlığın baş gösterdiği şeklinde bir telgraf çektiği bildirilerek gerekenin yapılması istenmiştir. ${ }^{53}$ Ticaret Bakanlığı'nın verdiği bilgiye göre, İzmir'in nahiye ve köylerinde kullanılmak üzere 81 ton buğdayın verildiği bildirilmiştir ${ }^{54}$.

Hükümet, yaşanan yetersizliklere önlem olarak Milli Korunma Kanunu'nun 13. maddesine dayanarak Ticaret Bakanlığı'nın daha fazla stok yapabilmesi için bütçeden emrine 500 bin liralık ödenek aktarmıştır. ${ }^{55}$

\section{BUĞDAY SIKINTISI KARŞISINDA ALINAN ACİL ÖNLEMLER}

Giderek ülkede kendini daha çok hissettiren buğday sıkıntısı, hükümeti daha s1k1 önlemler almaya itmiştir. Koordinasyon Heyeti Başkanlığı 14. 11. 1941 tarih ve 1/1902 say1li tezkere ile Bakanlar Kurulu'na bir tezkere yazarak, buğday unundan ekmek, francala, makarna, şehriye, peksimet, bisküvi ve simitten başka maddelerin yapılmasının, satılmasının ve tüketiminin yasaklanmasını istemiştir. İstek, 24 Kasım 1941 tarihinde Bakanlar Kurulu'nda görüşülerek kabul edilmiştir. ${ }^{56}$ Yasak kararının istisnas1 ise lokanta, mutfak ve evlerde yapılacak hamur işleridir. $\mathrm{Bu}$ gibi yerlerin un ihtiyacını ise Ticaret Bakanlığı tarafından karşılanmasına karar verilmiştir. Hastanelerde francala verilmesi gereken hastalar içinde gerekli tedbir alınması istenmiştir. Kararda yapılmaları ve satılmaları men olan maddelere de yer verilmiştir. Pasta, kek, sandviç ekmeği, poğaça, yufka, çörek, börek, tatlı ve emsali maddelerin imalatı yasaklanmıştır. Bu maddeleri imal eden şahıs ve kurumlar ise ellerinde bulunan unların vasıf ve miktarını bir beyanname ile üç gün içinde bulundukları yerin en büyük mülkî amirine bildirmeleri zorunlu tutulmuştur. Mülkî amirler de makbuz karşılığ 1 aldıkları bu mamulleri yine makbuz karşı1lı̆ında Toprak Mahsulleri Ofisi'nin en yakın şubelerine teslim etmekle yükümlü tutulmuş, ürünlere Ofisin bedelini peşin olarak ödemek üzere Milli Korunma Kanunu'nun 14 maddesine göre hükümet adına el koymakla yetkili kılınmıştır ${ }^{57}$.

Savaşın en çetin seyrettiği dönemde Türkiye gibi savaş dışı kalmış ülkeler de büyük sıkıntılarla karşı karşıya gelmiştir. İnsanlar için ekmeklik buğday, hayvanlar için yem sıkıntısı kendisini iyiden iyiye hissettirmeye başlamıştır. 1941 yılının sonlarına gelindiğinde hükümet halkın günlük

${ }^{53}$ BCA: $030.10 / 185.273 .2 . / 20.10 .1941$.

${ }^{54}$ BCA: 030.10/ 185.273.2/ 8. II. Tessrin 1941

${ }^{55}$ BCA: 030.18.01.02/ 96.86.2/ 8. I. Teşrin 1941.

${ }^{56}$ BCA: 030.18.01.02/ 96.95.17./ 24. II. Teşrin 1941.

${ }^{57} 24$.II. Teşrin 1941 tarihli Bakanlar Kurlu Kararı'nın ekidir. 1/1902. K/223 
ekmek tüketimine bir takım sınırlamalar getirme kararı almıștır. Bakanlar Kurulu 13 Şubat 1942 'de yeni önlemler almıştır ${ }^{58}$. Bu tarihten itibaren, şehir ve kasabalarda halkın ekmek ihtiyacını karne ile karşılamasına karar verilmiştir. Milli Koruma Kanunu'nun 21. maddesine göre kişinin günlük ekmek tüketimi sınırlandırıldığı gibi karne ile kupon karşılığında olacaktır. Yedi yaşına kadar çocuklar günde 287,5 gram, yedi yaşından büyükler 375 gram, ağır işlerde çalışanlar 750 gram ekmek tüketebilme hakkına sahip olacaklard $1 r^{59}$.

Genelgede günlük tüketim miktarının gramı verildiği gibi yerleşim yerlerinde karneyi kimin nasıl düzenleyeceği de ayrıntıları ile belirtilmiştir. Düzenleme özet olarak şu maddeleri içermektedir. ${ }^{60}$ :

1. Ekmek kartlarını o mahallin belediyeleri sorumlulukları altında yürütür. Bunun için idare amirlerinin denetiminde geçici bürolar kurulur. Bürolarda o yerde görevli bütün devlet memurları ve öğrencilerden ücretsiz olarak yararlanılacaktır. Ücret ancak resmi tatil günlerinde ve mesai saatleri dışında günde beş lirayı geçmeyecek şekilde ödenir.

2. Ağır işçi: Sanayide, maden ve taş ocaklarında, bina, yol, köprü ve benzeri inşaatta, nakil, yükleme-boşaltma, orman işçisi, şiddetli hararet, 1şık, gürültü, solunumu zorlayacak gaz ve sağlı̆ 1 etkileyici bozuk havalı ortamlarda çalışmak zorunda bulunan kişilerdir.

3. Tanzim satışı yapılan köylerde, büyük küçük yaş haddi gözetilmeksizin nüfus başına günlük 300 gram ekmeklik buğday verilir.

4. Tanzim satışı yapılmayan şehir, kasaba ve köylerde yaş grubuna göre yapılan düzenleme miktarını aşacak ekmek verilmez.

5. Buğday ve un satışı şöyle düzenlenmiştir: Buğday ve diğer ekmeklik hububat unlarından ekmekten gayrı unlu maddelerin yapılması ve satılmas1 menolunmuştur. Lokantalarda resmi daire ve kurumlar ile şahıslar tarafindan işlettirilen aşevlerinde yapılacak hamur işleri de yasaklanmıştır. Ancak Ticaret Bakanlığının tayin edeceği zamanlarda ekmek karnesinin muayyen kuponu karşılığında ekmek yerine un verilebilir. Hükümet lüzum gördüğü zaman önlem olarak peksimet stoku yaptırabilir.

6. Buğday ve ekmeklik unlardan yapılmış, satılması ve tüketimi yasaklanan ürünleri üreten, satanların ellerindekilere hükümet el koyar. $\mathrm{Bu}$ sebeple ellerinde un ya da mamul bulunduranlar bir beyanname ile

\footnotetext{
${ }^{58}$ BCA: 030.18.01.02/ 97.108.8/ 13 II. Kanun 1942.

${ }^{59}$ BCA: 030.18.01.02/97.108.8

${ }^{60}$ A.g.b.
} 
bildirmeye mecburdurlar. Ancak beyanla verilen mamullerin değeri maliyetin üzerine \%10 kar konarak ödenmek zorundadır.

Yukarıda alınan önlemlerden anlaşılacağı üzere hükümetin politikası ülkede meydana gelebilecek açlığı ve neden olabilecek sonuçlarını önlemeye yöneliktir. Böylece uzun süre devam edecek olan ülkede "ekmek karnesi” ile yaşam bu tarihten itibaren başlamıştır.

Orduda askerin günlük ekmek tüketimi ise yine Bakanlar Kurulu kararı ile 750 grama indirilmiştir ${ }^{61}$. Karar Mili Savunma Bakanlığı'nın emri ile 8 Mayıs 1942 'de yeniden tadil edilerek asker başına 600 grama indirilmiştir ${ }^{62}$.

Kimlerin ağır işçi olacağı hükümet kararnamesi ile belirtilmesine rağmen belediyelere bazı meslek gruplarından kişiler ağır işçi olduğu gerekçesi ile müracaat etmişlerdir. Odacı, kapıcı ve dağıtıcılar ağır işçi oldukları gerekçesi ile fazla ekmek talebinde bulunmalarına rağmen, bu istekleri kabul edilmemiştir ${ }^{63}$. Diğer yandan bazı kişiler ekmek karnesini kaybettiğinden zorluklarla karşılaşmışlar, yetkililer bu kişilerin mağduriyetlerini yeni karne vermek suretiyle gidermişlerdir ${ }^{64}$.

Aynı yılın Şubat ayında alınan gizli bir kararla şehir ve kasabalarda buğday, çavdarın yanına mısır da eklenerek bedeli ödenmek koşulu ile el konulacağı kararı alınmıştır. Kararın yayınlanması ise yasaklanmışıtır ${ }^{65}$. Nisan ayında alınan başka bir gizli karara göre ise unlara diğer bakliyat ürünlerinin de katılacaktır. Karışımdan doğan fiyat farklılıkları ekmeğe yansıtılmayacaktır ${ }^{66}$. Kömür madeni çıkaran devlet işletmelerinde, ocakta çalışan işçiler için günlük 1000 gram, dışarıdaki işçiler için 750 gram ekmek tüketimi uygun görülmüştür ${ }^{67}$.

İstanbul'un nüfusunun yaklaşık bir milyon olması, ilin buğday üretim bölgesi olmaması ve en önemli tüketim merkezi olması, buğday ve un temini konusunda güçlükler çıkarmıştır. Dönemin belediye Başkanı ve Valisi olan Lütfü Kırdar durumun nezaketini başbakanlığa bir rapor halinde yazmıştır. O dönemde İstanbul'un ihtiyacını karşılayacak asgari hububat ihtiyacının 15 vagon olduğu ve durumun ciddiyetine vurgu yapılarak, İstanbul'un iaşe sorununun çözümü için bir karar çıkarılması istenmiştir ${ }^{68}$.

${ }^{61}$ BCA: 030.18. 02./ 97.120.3/ 23.02.1942

${ }^{62}$ BCA: 42/89 Numaralı Karar/ 8.5.1942

${ }^{63}$ BCA: $030.10 / 25.116 .10 / 22.01 .1942$.

${ }^{64}$ BCA: $030.10 / 25.166 .10 / 19.02 .1942$.

${ }^{65}$ BCA: $030.18 .01 .02 / 97.123 .20$. EK. 9/220

${ }^{66}$ BCA: $030.18 .01 .02 / 98.26 .16 /$ EK: $1 / 411$

${ }^{67}$ BCA: 030.18.01.02/ 99.75.13/ 15 Ağustos 1942.

${ }^{68}$ BCA: $030.10 / 83.544 .13 / 21.10 .1941$. 


\section{EKMEK KARNESİ VE DİĞER İAŞELERİN DAĞIMIMINA ILLISKIIN TALIMATNAME}

Ülkede temel gıda maddesinin temini sıkıntısına çözüm yolu aranırken dağıtımı ile ilgili güçlükler de ortaya çıkmıştır. Hükümet, 22 Ekim 1942'de hazırladığı talimatname ile dağıtımın kimler tarafından ve nasıl yapılacağına ilişkin ayrıntılı bir düzenlemeye gitmiştir. $\mathrm{Bu}$ düzenlemede karnelerin kimlere verileceğinden, gruplandırılmasına kadar düzenlemede ayrıntılı bilgiler verilmiştir. Talimatname bütün devlet memurlarını işçilerini, emekli dul ve yetimleri ve bu kimselerin bakmakla yükümlü olduğu kişileri kapsamaktadır. Talimatnamenin kapsamı 17 maddeden oluşmuştur. ${ }^{69}$ Ayrıntılı düzenlemeler yapılmasına rağmen karne dönemi boyunca hangi meslek grubunun ya da iş kolunun ağır iş kapsamına girdiği çalışanlar tarafından anlaşılamadığı yapılan müracaatlarda anlaşılmaktadır. Doğrudan bakanlıklara veya bağlı bulundukları kurumlara başvurarak günlük ekmek tüketim gramını yükseltme istekleri eksik olmamıştır. Gerek bakanlar kurulu yayınladığı kararnamelerle, gerekse ilgili bakanlıklar sık sık iş kollarındaki kişilerin günlük ekmek tüketimi gram miktarını belirtmek zorunda kalmıştır ${ }^{70}$.

İstifade edecek olanlar, iki nüsha olarak durumunu bildiren beyannameyi dolduracaklar ve mensup oldukları daireye teslim edeceklerdir. Emekli, dul ve yetimlerin beyanları ise bağlı oldukları sandıklar tarafindan hazırlanarak ilgili birimlere verilecektir. Teslim edilen devlet daireleri ise beyannameleri bağlı kazalara, kazalar vilayetlere, vilayetler ise Toprak Mahsulleri Ofisi genel merkezine göndereceklerdir. Böylece ülkenin ihtiyacı olan ekmek ve mahsul miktarı belirlenmiş olacaktır.

Ekmek karneleri, Ticaret Bakanlığı tarafından hazırlanacak ve soğuk damgalı olacaktır. Dağıtımı valilikler tarafından yapılacaktır. Aile reisinin ölümü durumunda o ailenin karnesi yeniden düzenlenecektir. Yine aileden birisinin ölümü durumunda o aile reisinin karnesindeki ölen kişinin ekmek kuponu geri alınır. ${ }^{71}$ Ayrıca Ankara, İstanbul, İzmir gibi vilayetlerde ekmek karnesine ailenin reisinin resmi yapıştırılırken diğer vilayetler için bu zorunluluk yoktur. Karneden başka her mahalli çevrenin yönetimi ekmek kartı hazırlayarak yararlanacaklara verecektir. Kişiler ekmek ihtiyacını

\footnotetext{
${ }^{69}$ BCA: 030.18.01.02/ 120.89.19/22.10. 1942

${ }^{70}$ BCA: 030. 18.01.02/ 101.6.16/22.01.1943

71 Ankara Valiliği Evrak Müdürlüğünde çalışan S.G. isimli memurun çocuğu vefat ettiğinden ve 794 sayılı, ana karne sahibi Neşriyat ve Müdevvenat Umum Müdürlügü Memuru m. K. in da karısı E. den ayrılmış olduğundan ana karnelerinden ve iaşe beyannamelerinden çıkarılmasına ait muamelenin yapılmasına emir ve müsaade buyrulmasını saygılarımla arz ederim
} 
belediyenin belirlemiș olduğu firınlardan alacaklar, eğer aileden birisi yer değiştirmek durumunda kalırsa aile reisi bulunduğu belediyeye bildirmek suretiyle o kişi ekmeğini bulunduğu belediyeden alabilecektir.

Ekmek dağıtımı yapılmayan yerlerde, yine bağlı bulundukları yerel yönetimler tarafindan un veya buğday verilecektir.

Şeker ve diğer maddelerin dağıtım şekli ise farklılık göstermektedir. Şeker dağıtımı için üç bölge belirlenmiştir: Şeker şirketinin teşkilatı olan vilayetler, demir ve deniz yolu güzergâhı olan vilayetler, bunların haricinde kalan vilayetler. Birinci grupta yer alan yerlerde doğrudan şeker şirketi dağıtım yapacaktır. İkinci gruba dâhil olan vilayetlere şirket şeker naklini yapacaktır. Üçüncü gruba dâhil olan dağıtımı, şeker şirketi en yakın vilayete naklederek, ihtiyacı olan valiliğin görevlendirdiği memurlara teslim edecektir. Dağıtım birinci ve ikinci grup için üçer aylık ihtiyaca göre, üçüncü grup içinse altı aylık olarak yapılacaktır ${ }^{72}$.

Ülkenin içinde bulunduğu durumun ne kadar zor olduğu hükümetin aldığ 1 önlemlerden anlaşılmaktadır. Halk bir taraftan muazzam zorluklar çekerken, dönemin devlet ve hükümet adamları çaresizliklerini ve çıkmazlarını yüksek sesle dile getirmişlerdir. Cumhurbaşkanı İnönü 1 Kasım 1942'de Meclis açış konuşmasını yaparken tepkisini Mecliste öfkeli konuşmasıyla dışa vurmuştur. Bir takım kişiler yokluk ve sıkıntılardan yararlanarak, karaborsacılık, stokçuluk yapmışlar ve muazzam kârlar elde etmişlerdir. Cumhurbaşkanı İnönü, yaklaşık iki yıldır ülkede 1stırap çekildiğini, bu 1stırabın dindirilmesi için Cumhuriyet Hükümetinin var gücüyle çalıştığını söylerken, toplumun kendilerine yardımcı olmadığından yakınmıştır ${ }^{73}$. Konuşmasında bir kısım çiftlik ağaları ile tüccarlara şöyle tepki göstermiştir. ${ }^{74}$ :

"Bu devirler harbe girmiş veya girmemiş memleketlerin hiç birisi için, engin kazançların bulunmaz firsatları değildirler. Istırabı azaltmak, millet tahammülünü arttırmak, muharebe dışında kalmak ve muharebeye girilirse şerefle ve selametle çıkmak için tek çare resmi vazife sahiplerine ve en başında Cumhuriyet Hükümetine yardım etmektir.... Acı ile hatırlatmalıyız ki milletin iaşe işlerini tanzim etmek yolunda Cumhuriyet hükümetlerinin sarf ettikleri gayretlere, iki seneden beri, cemiyetimiz tarafından hiç yardım edilmemiştir.

72 030.18.01.02/ 100.89.19. Talimatname beyanname örnekleriyle birlikte 15 sayfadan oluşmaktadır.

73 İnönü'nün Söylev ve Demeçleri I T.B.M Meclisinde ve C.H.P. Kurultaylarında (19191946) Türk Devrim Tarihi Enstitüsü Yayınları, Milli Eğitim Basımevi, İstanbul, 1946,s.370.

74 a.g.e. s. 371 . 
(...) Bulanık zamanı bir daha ele geçmez firsat sayan eski batakçı çiftlik ağası, elinden gelse teneffüs ettiğimiz havayı ticaret meta1 yapmaya yeltenen gözü doymaz vurguncu tüccar ve bütün bu sıkıntıları politika ihtirasları için büyük firsat sanan ve hangi yabancı milletin hesabına çalıştığı belli olmayan birkaç politikacı, büyük bir milletin bütün hayatına küstah bir surette kundak koymaya çalışmaktadır."

Doğan Avcıŏ̆lu, o sert sözlerin bir yakınmadan öteye geçmediğini ${ }^{75}$, bu dönemde Türkiye'de stokçuluk, karaborsacılık yoluyla çok sayıda zengin türediğini yazmıştır. Başbakan Refik Saydam'ın tüccarların devlet ve millet hayatında gerekli bir unsur olarak kabul ettiğini söyledikten sonra, kendilerinin istediği gibi hareket etmemesi durumunda devlet ve millet hayatında gerekli bir unsur olmaktan çıkarabilecekleri yönünde tehdit ettiğini belirtmiştir. Başbakan, tüccarlara karşı önlem olarak ithalatı tamamen devletleştirebileceklerini söylemesine rağmen; daha önce dile getirdiği önlemler alınmamış, şikâyet edilen kesimlerin savaş koşullarında yasadış1 zenginleşmelerinin önüne geçilememiştir ${ }^{76}$. Çok partili hayata geçilmesiyle birlikte, savaş zamanında hükümet uygulamalarına ilişkin olarak, karş1 partililerce Cumhuriyet Halk Partisi eleştirilmiş, yine siyasi hayatta faal olarak Demokrat Parti ve Cumhuriyet Halk Partisi'nde savaş zenginlerinin olduğu iddiası eksik olmamıştır.

Yine, Cumhurbaşkanı İnönü'nün çeşitli kesimlere tepkili olduğu tarihlerde, görevlendirilen bir kısım mutemet ve mümessillerin de yolsuzluk yaptıkları hükümete ihbar edilmiştir ${ }^{77}$. İçişleri Bakanlığı'na intikal eden

75 Doğan Avcığlu, Türkiye'nin Düzeni (Dün bugün,Yarın), C:I, Tekin Yayınları, İstanbul 1996, s.474.

${ }^{76} \mathrm{O}$ dönemde tüccarların bir kısmı ithalat yapanların dışarıdaki alıcıyla anlaşarak ihracat fiyatlarını düşük tutmuşlar, sahte faturalarla ithalat fiyatlarını yüksek göstermişlerdir. Avcıoğlu, o dönemde anlatılanların somut bir örneğini CHP'li olduğunu öne sürdüğü bir tüccar üzerinden vermiştir. İsim belirtilmemiş, partide ileri gelen bir kişi olarak nakletmiştir. "Yı1 1943. İzmir CHP Teşkilatının önemli kişilerinden önemli bir tüccarın deri balyaları arasında yünleri kırpılmamış deriler ihraç ettiği ihbar edilmiştir. Yani tüccar değersiz deri ihraç ediyormuş gibi göstererek aslında altın değerinde bir yünü kaçak olarak ihraç etmektedir. Bu yolla sağlanan döviz dışarıda bırakılmaktadır. İhbar üzerine harekete geçen müfettiş olayın doğruluğunu tespit etmiştir. Ayrıca ünlü tüccarın yazıhanesinde bulunan Fransızca mektup bu ihracatçının yabancı bir firmaya casusluk yaptığını " Türkiye sıkışık, düşük fiyat verin" diye haberler yolladığını gösteren bir belgedir. Mektupta tüccar yaş deri üzerindeki yünlerin bedelini de bildirerek deriden ayrı fiyatlandırmaktadır. Tüccar, firmayla önceden yaptığı anlaşmaya göre paranın dolar cinsinden verdiği hesap numarasına yatırilmasin 1 istemektedir.

Müfettiş gerekli işlemi yaparak, bakanlığa raporunu vermiștir. Tüccarın tepkisi ise ticari şerefinin çiğnendiğini ileri sürerek partisine küsmüş, Demokrat Parti kurulunca, bu yeni partiye geçmiştir.” A.g.e., s. 474

${ }^{77}$ BCA: 030.10/ 68.449.8/ 26.11.1942. 
ihbar ve șikâyetler neticesinde ortaya çıkarılan bu gibi durumların azımsanamayacak sayıda olduğunu belirtmeliyiz. Hububat Mübayahası işleri üzerine Polatlı'da Yapılan Tahkikat başlığını taşıyan raporda, Zonguldak, Geyve, Konya, Kayseri, İnebolu belediyelerinde görevli mutemetlerin, aldıkları buğdayların fiyatlarını fazla göstererek sattıklarının tespit edildiği yazılıdır. Tespit edilen kişiler hakkında soruşturma başlatıldığını ve gerekli cezai işlemin yapılacağı bildirilmektedir. Memurların her birinin yolsuzluğuna konu olan buğday miktarı tonlarla ifade edilmektedir ${ }^{78}$. İçişleri Bakanlığ1 ve Ticaret Bakanlığ1 ortak bir düzenleme ile dar gelirli vatandaşların ekmeksiz kalmamaları için de önlemler almış ve valiliklere bu önlemler bildirilmiştir ${ }^{79}$.

\section{7. ÖNLEMLERIN HAFIFLETILMESI}

İkinci Dünya Savaşı'nın sonuna yaklaşıldığının anlaşılması bir anlamda Türkiye'nin savaş dışında kalacağı umudunu doğurmuştur. Savaşın sona ereceğine dair belirtilerle birlikte ülke içinde temel ihtiyaç maddelerinin temini ve dağıtımı konusunda alınan sıkı tedbirlerin hafifletilmesine yönelik kararlar alınmaya başlamıştır. Milli Savunma Bakanlığı Levazım İşleri Dairesi'nin 31406 sayılı genelgesine göre, isteyen subaylara ekmek yerine un verilmesinin serbest olduğu bildirilmiştir. 21 Ocak 1944 y1lında temin edilen hububatın önceki yıllara göre ihtiyacı karışlayacak ölçüde olduğu, maliyetlerin azaltıldığı, günlük ekmek hakkının 900 gram $^{80}$ olduğu bildirilmiştir. Hükümetin daha fazla hububat stoku yapabilmek için alım fiyatlarını yükseltmesi, üreticinin buğdayı Toprak Mahsulleri Ofisine daha çok mahsul satmasını sağlamıştır. Yalnız stokçuluk yapan tüccarın kârlarını arttırmasına engel olamamıştır. Halk açısından faydası daha önce unlu gıdaların üretimi, tüketimine ilişkin konulan yasakların kalkmasını ${ }^{81}$ sağlamıştır. Devlet eliyle stok yapılması, bu dönemde bir yönüyle fiyat artışlarını kontrol etmeye yönelik olduğunu görüyoruz. Buğdayın yanı sıra yağ, şeker, tuz, sabun gibi temel tüketim maddelerinin fiyatını ucuzlatmaya yönelik çabalarının sonuç verdiğ $i^{82}$ kararlarda olumlu bir gelişme olarak belirtilmiştir.

Bundan başka Hükümetin, diğer ihtiyaç maddelerinin temin edilmesine yönelik çalışmalar yaptı̆̆ 1 yine yayınladığı genelge ile izah edilmektedir. Çimento ve mensucat maddelerinin fiyatlarının ucuzlatılması için devletin

${ }^{78}$ BCA:030.10./ 68.449.8/ 25.11.1942.

${ }^{79}$ BCA: 030.18.01.02/ 100/110.9/ 6.1.1943.

${ }^{80}$ BCA: 030.10./ 50.325.19/2 I.Kanun 1944.

${ }^{81}$ BCA.: 030.01./ 98.606.1

${ }^{82}$ Adı geçen belge. 
doğrudan müdahale ettiği anlatılırken, darlı̆̆ 1 çekilen maddelerin ithalat yoluyla giderileceği bilgisi de verilmektedir. Dar gelirlilere doğrudan yardım yapılmaya çalışıldığı, memur dul ve yetimlere nüfus başına altışar kilo şeker, onar kilo sabun dağıtıldığ 1 , üç büyük şehirde on ikişer kilo un verildiği bildirilmiştir. $\mathrm{Bu}$ maddelerin ne kadar süre için verildiği belirtilmemiştir. Verilen bilginin önemi, miktarından ziyade önceki yıllarda ülkenin içinde bulunduğu sıkıntıyı aşıyor olması bakımından aydınlatıcı olmasıdır. O yıllarda sıkıntının sadece gida maddelerinde yaşanmadığı giyecek ve ev eşyası gibi maddelerin temininde de zorluklar olduğu anlaşılmaktadır. Çeşitli şehirlerde yerli malları pazarları kurularak halkın ucuz eşya bulmasının sağlandığına ${ }^{83}$ işaret edilmektedir. Raporun sonuç bölümünde ise harp sonunun yaklaştığı, ama ülkede sorunların bitmediği belirtilirken, ülkenin genel iktisadi sorunlarına göndermeler yapılmıştır. Yurt içinde fiyatların dünya fiyatlarından yüksek olmasının, ihracatta sorunlar yaratacağı bilgisi verilmiş, ihracatta ve ithalatta sorunlar olacağına değinilmiştir. Avrupa ülkeleri ile ticaretin tamamen durmasının başlıca sorunlardan biri olduğu vurgulanırken çözüm için müttefiklerden yardım beklentisi ${ }^{84}$, Türkiye'nin dış siyasetinin ne şekilde olacağının işaretleri verilmektedir.

Dünya Savaşı'nın sona ermesi hükümetin aldığı olağanüstü tedbirleri hemen kaldırmamıştır. Dönemin Bakanlar Kurulu'nda insanların günde kaç gram ekmek tüketeceğine ilişkin kararlar çıkmaktadır. ${ }^{85}$ Önceki yıllarda alınan kararlardan farkı, günlük tüketim miktarının arttırılmasıdır. Değirmenlerde düşük randımanlı un yerine daha yüksek randımanlı un ögütülmesine izin verilirken, insanlar halka yine karne ile ekmek verilmesi, ama miktarının biraz yukarı çekilmesinden anlaşıldığına göre olağanüstü koşulların devam ettiğini göstermektedir.

Savaş bitmiş, üzerinden bir yıl geçmiş olmasına rağmen, 1946 yılında da ülkede çekilen sefalet ve yokluk devam etmiştir. Dönemin milletvekillerinden Eşref Dizdar ve İhsan Gürak'ın Sağlık Bakanı Sadi Konuk'a çektiği telgrafta ülkenin bazı bölgelerinde insanların gıda sıkıntısı çektiğini göstermektedir ${ }^{86}$. Giresun'dan çekilen telgraftan anlaşıldığına göre bölgede açlik tehlikesinin olduğu, yaşanabilecek felaketin önüne geçilebilmesi için üç bir ton mısıra ihtiyaç duyulduğu bildirilmiştir. Sağlık Bakanlığ 1 ise gereğinin yapılacağ 1 bilgisini vermiştir.

83 BCA: 030.01/ S98.606.1.

84 Adı geçen belge.

85 BCA: 030.10.01.02/ 108.22.1/ 10.04.1945.

${ }^{86}$ BCA: 030.10/177.224.7/ 19.03.1946. 
Yine halkın ve hükümetin karşı karşıya olduğu durumun zorluğunu vatandaşlardan gelen şikâyetlerden anliyoruz. Gelen şikâyetlerin değerlendirilmesi ve gerekli müdahalenin yapılması, hükümetin düzensizliğin önüne geçme çabası olarak değerlendirilmelidir. Şikâyetlerin birçoğunun hükümetin uygulamalarından kaynaklandığı göz önüne alınacak olursa olağanüstü bir dönemin yaşanmasına rağmen vatandaşların istek ve şikâyetlerini dikkate almasının önemli olduğu kanaatindeyiz.

Adana'da arzuhalcilik yapan bir vatandaşın TBMM Başkanlı̆̆ı'na yazdığ 1 şikâyet dilekçesi, insanların çektiği sıkıntıların devam ettiğini ortaya koymaktadır. Aile nüfusunun dokuz kişiden oluştuğunu, her ay dört kuruş karne parası, bir kuruş pul parası verdiğini, altı ekmek karnesini ödediği halde üç tanesini ödeyemediğini yazmıştır. Kendisi gibi ödeyemeyen kişiler olduğundan, duruma bir çaresinin bulunmasını istemektedir. ${ }^{87}$ Amacının kimseyi şikâyet etmek olmadığını, fakat alınan paraların kendilerine yük olduğunu dile getirmiştir. Başbakanlık Özel Kalem Müdürlüğü'nün verdiği cevap, karne başına üç kuruşun kâğıt masrafları için, bir kuruşun ise Çocuk Esirgeme Kurumu'na ayrıldığı, usulsüz bir durumun olmadığ 1 şeklindedir. Konya'dan emekli bir subay ise Karaman'da kişi başına aylık 200 gram kahve verildiği halde Konya'da yüz gram verildiğinden yakınmaktadır. Başbakan Recep Peker'e yazdığ 1 mektupta, kendisinin Karaman'dan Konya'ya taşındığını, eski ikametgâhında iki yüz gram kahve verilirken yüz grama düşürüldüğünü bu durumu kendisi için gurur kırıcı olduğundan yakınmıştır. Karaborsa'da kahvenin sekiz liradan satıldığı bilgisini verdikten sonra durumunu anlatmasının sebebini eski bir subay olmasından cesaret aldığını ${ }^{88}$ belirtmiştir. Başbakanlık tarafından verilen cevapta, şikâyetin incelendiğini, verilen kahvenin yerleşim yerlerine göre nüfus başına belirlendiğini, o yüzden iki yerleşim yerinin ihtiyacının farklı olduğunu, yeni yerleşim yerinde yüz gram almasının yasal olduğu bildirilmiştir. Ayrıca bir kişinin emekli bir subay olmasından ötürü diğer vatandaşlardan ayrı tutulamayacağ ${ }_{1}^{89}$ bilgisi de verilmiştir.

Her ne kadar İkinci Dünya Savaşı ülke toprakları dışında gerçekleşmiş olsa bile hem yönetenler, hem halk zor seneler geçirmiştir. İnsanların en temel gereksinmesi olan beslenme ihtiyacının karşılanması belli bir süre asgari koşullarda gerçekleşmiştir. Bir anlamda halkın büyük bir kesimi yıllarca karnını hükümetin verdiği kararlarda belirttiği gibi doyurmak zorunda kalmıştır.

${ }^{87}$ BCA: 030. 01/ 65.401.6/ 17.01.1946.

${ }^{88}$ BCA: No: 189, 2.09.1946.

${ }^{89}$ BCA: 030.01./ 78.487.9/ 26.09.1946. 


\section{SONUC}

Türkiye Cumhuriyeti'nin kurulmasından itibaren ekonomik ve siyasal alanda yaklaşık her on y1lda bir kriz yaşamıș, bu krizlerin etkisini ülke yoğun olarak hissetmiştir. 1929 dünya ekonomik bunalımını ikinci bir parti denemesiyle aşmayı deneyen Türkiye, beklenen başarıyı elde edememiştir. Sonrasında, tek parti yönetimi ve devletçi bir anlayışla planlı kalkınma modelini uygulamasına rağmen, sanayileşmesini tamamlayamadığı gibi askerî ihtiyaçları ve sanayi üretiminde henüz dışarıya bağımlı olduğu bir dönemde ikinci bir krizle karşı karşıya gelmiştir. Savaş yıllarında dışarıdan gelebilecek her hangi bir saldırıya karşı hazırlık yaparken dönem boyunca üretim ve tüketimindeki daralmanın etkisiyle halka temel ihtiyaç maddelerinin temininde güçlükler yaşamıştır. Ülke yönetimi otoriter bir siyaset anlayışı ile ülke kaynaklarını kontrolü altında tutma ve kaynaklarını gerekli gördüğü miktarda harcama ve tasarruf etme yolunu seçmiştir.

Savaş süresince, temel gıda maddeleri ile ilgili alınan kararların, doğabilecek olumsuzlukları önlemek adına emredici ve men edici olduğu dikkati çekmektedir. Diğer yandan, zorlayıcı kararların alınmasının nedenlerinin açıklamasının yapılması, kararı alan siyasal iradenin keyfilikten uzak durmak istediğini düşündürmektedir. Hangi madde ile ilgili karar alınmışsa, nedeni yine o karar içinde açıklanmıştır. Kararların uygulanmasının yasal bir dayanağının olması doğal olarak cezai yaptırımları da içermektedir. Hükümetin beklentisi alınan kararlara bütün kesimlerin uyması şeklinde olup, kararların uygulanmasını aksatan stokçu, karaborsacı tüccara, rüşvet alan memurlara, uygulamayı aksatan topluma tepkiler siyasal yönetimin her kademesinden eleştiriler biçiminde gelmiştir. Savaşın biteceğinin belli olması, ülkede temel maddelerin bollaşmaya başlaması sıkı tedbirlerin hafifletilmesi biçiminde olmuştur. Yine aynı şekilde hafifletilme gerekçeleri anlatılırken toplumun yoksul kesimi, dul ve yetimler, kimsesizlerin korunup kollanması vurgusu yapılmıştır.

Sonuç olarak, alınan bütün tedbirlerin, zorunluluktan kaynaklandığı hükümetin aldığı kararlarda açıklanırken, hükümetin benimsediği yol, ülkenin savaşa girmemesine rağmen olağanüstü tedbirlerle halkı toplu bir açlık tehlikesinden korumak biçiminde ortaya çıkmıştır. İzlenen politikanın temel gerekçesi, dışarıdan gelebilecek bir saldırıya karşı topyekûn bir mücadeleye hazır olunması biçiminde şekillenmiştir. Ülke yönetiminin, orduyu dış saldırıya karşı hazır tutarken, aldığı kararların uygulanmasında özendirici yollar yerine otoriter bir yönteme başvurduğu, jandarma kuvvetinden yararlanarak uygulamasından anlaşılmaktadır. Diğer yandan ülke yönetiminde siyasal partilerin halk tarafından değerlendirilmesi tekrar iktidara gelmesini sağlayacak oy toplamasına bağlıdır. Dönemin iktidarını 
elinde tutan Cumhuriyet Halk Partisini ve birinci adamı İsmet İnönü’ye halk tepkisini göstermek için çok partili yaşama geçilmesini beklemiş, bu yılların sıkıntılarını seçim meydanlarında dile getiren rakip partileri tercih etmiştir.

\section{KAYNAKÇA}

Ağaoğlu, Ahmet; Serbest Fırka Hatıraları, İletişim Yayınları, İstanbul, 1982.

Arı, Kemal; İkinci Dünya Harbi ve Türkiye, Genelkurmay Askerî Tarih ve Stratejik Etüt Başkanlığı Yayınları, Ankara, 1998.

Avcıoğlu, Doğan; Milli Kurtuluş Tarihi Cilt:4, Tekin Yayınevi, İstanbul, 1996.

Aydemir, Şevket Süreyya; İkinci Adam; Remzi Kitabevi, C: II, İstanbul, 1991.

Aydemir, Şevket Süreyya; Tek Adam Mustafa Kemal, C: 3, Remzi Kitabevi, İstanbul, 1995.

Boratav, Korkut; Türkiye'de Devletçilik, Savaş Yayınları, Ankara 1982.

Cebesoy,Ali Fuat; Siyasi Hatıralar, II. Kısım, Doğan Kardeş Yayınları, İstanbul, 1960.

Duru, Bülent; 1931 Tasarruf Yılı: Tek Partili Dönemin Başlangıc1; Türkiye Cumhuriyeti İdare Tarihi Araştırması (T.D.ATA), A.Ü. Siyasal Bilgiler Fakültesi Kamu Yönetimi Araştırma ve Uygulama Merkezi 2, Ankara, 2007.

Gönlübol, Mehmet; Olaylarla Türk Dış Politikası 1919-1990, Siyasal Kitabevi, Ankara 1993.

Güner, Agah Oktay; Türkiye’nin Kalkınmast ve İktisadi Devlet Teşekkülleri; Damla Yayınevi, İstanbul 1978.

Inönü'nün Söylev ve Demeçleri I T.B.M Meclisinde ve C.H.P. Kurultaylarında (1919-1946) Türk Devrim Tarihi Enstitüsü Yayınları, Milli Eğitim Basımevi, İstanbul, 1946.

İpekçi, Abdi; “İnönü Dünya Savaşı Anılanı Anlattı”, Milliyet, 06.05.1973

Kandemir; Siyasi Darginlıklar: Serbest Fırka Nasıl Kuruldu Nasıl Kapatıldı?, Ekincigil Matbaası,

Keser, İhsan; Türkiye'de Siyaset ve Devletçilik, Gündoğan Yayınları, Ankara, 1993.

Kili, Suna; Türk Devrim Tarihi, Türkiye İş Bankası Kültür Yayınları, İstanbul 2000.

Koçak, Cemil; "Siyasal Tarih 1923-1950”, Çağdaş Türkiye 1908-1980, Editör: Sina Akşin, Cem Yayınları, İstanbul, 1995. 
Makal, Ahmet; "65.Yılında Koruma Kanunu Çalışma İlişkileri ve İş Mükellefiyeti”Ankara Üniversitesi Siyasal Bilgiler Fakültesi gelişme ve Toplum Araştırmaları Merkezi Tartışma Metinleri No: 76, Ankara 2004

Nadi, Nadir; Perde Aralığından, Çağdaş Yayınları, İstanbul, 1991.

Uyar, Hakkı; “Tek Parti Döneminde Seçimler”, Toplumsal Tarih Dergisi, İstanbul, Nisan 1999.

Weisband, Edvard; İkinci Dünya Savaşı’nda İnönü’nün Dış Politikası, Cumhuriyet, Çağdaş Matbaacılık, İstanbul 2000.

Yetkin, Çetin, Türkiye'de Tek Parti Yönetimi 1930-1945, Altın Kitaplar Yayınevi, Birinci Baskı, İstanbul, 1983.

Yetkin, Çetin; Serbest Cumhuriyet Fırkası Olayı, Karacan Yayınları, İstanbul, 1982.

Yılmaz, Mustafa, Doğaner Yasemin; Cumhuriyet Döneminde Sansür, Siyasal Kitabevi, Ankara, 2007.

Yüce, Ali; "Şeytanistan”, Dizi yazı, Milliyet, 01.10.1970,

www. tbmm.gov.tr/Hükümetler/ HB11.htm, Erişim Tarihi 24.01.2010.

www. tuik.gov.tr/yıllık/İst_gostergeler.pdf, Erişim Tarihi 28.01.2010.

www. tuik.gov.tr/yıllık/İst gostergeler.pdf, Erişim Tarihi 28.01.2010.

www.tuik.gov. tr, Erişim Tarihi: 28.01.2010.

Başbakanlık Cumhuriyet Arşivi; 030. 18. 01. 02/ 85. 118.16

BCA: 030. 10.01.02/ 50. 322. 12.

BCA: 030. 10/50/322/11/24. 08. 1940.

BCA: 030. 10./ 45.290.56/26. 10. 1940.

BCA: 030. 10./184.27.2/ 16.12.1940.

BCA: 030. 10./184.271.2/17. 12. 1940.

BCA: 030. 10/184.271/2

BCA: 218- Çorum 575 / 17/12-17/ 17. 12. 1940.

BCA: 030. 10/184. 271. 1.

BCA: 030. 10/ 184. 272. 1.

BCA: 030. 10/ 185.273.5. 12. 02. 1941. No: 6-249/523

BCA: 030. 10/ 185.273.5 12.02.1941, No: 12098

BCA: 030. 18.01/94.49.1/ 18. 2. 1941. 
BCA: 030. 18.01.02/ 95.49.1/ 6. 6. 1941.

BCA: 030. 10. / 50.323.5/30. 06. 1941.

BCA: 030. 10/ 65.436.10./ 23. 10. 1941.

BCA: 030. 10/ 65.436.10/ 29. 08. 1941.

BCA: 030. 10/ 185.273.2./ 20. 10. 1941.

BCA: 030. 10/ 185.273.2/ 8. II. Teşrin 1941

BCA: 030. 18.01.02/96.86.2/ 8. I. Teşrin 1941.

BCA: 030. 18.01.02/ 96.95.17./ 24. II. Teşrin 1941.

BCA:24. II. Teşrin 1941 tarihli Bakanlar Kurulu Kararının ekidir. 1/1902. K/223

BCA: 030. 18. 01. 02/ 97.108.8/ 13 II. Kanun 1942.

BCA: 030. 18.01.02/97. 108. 8

BCA: 030. 18. $02 / 97.120 .3 / 23.02 .1942$

BCA: 42/89 Numaralı Karar/ 8. 5. 1942

BCA: 030. 10/ 25. 116. 10/ 22. 01. 1942.

BCA: 030. 10/25. 166. 10/ 19. 02. 1942.

BCA: 030. 18.01.02/97. 123. 20. EK. 9/220

BCA: 030. 18.01.02/98.26. 16/ EK: 1/411

BCA: 030. 18. 01. 02/ 99. 75. 13/15 Ağustos 1942.

BCA: 030. 10/ 83. 544. 13/21. 10. 1941.

BCA: 030. 18.01.02/ 120. 89. 19/22.10. 1942

BCA: 030. 18. 01.02/ 101.6.16/22.01. 1943

BCA: 030. 18. 01.02/ 100.89. 19

BCA: 030. 10/ 68. 449. 8/ 26. 11. 1942.

BCA: 030. 10./ 68. 449. 8/ 25. 11. 1942.

BCA: 030. 18. 01. 02/ 100/110. 9/6. 1. 1943.

BCA: 030. 10./ 50. 325. 19/ 2 I. Kanun 1944.

BCA: 030. 01./ 98. 606. 1

BCA: 030. 01/ 98.606. 1.

BCA: 030. 10. 01. 02/ 108. 22. 1/ 10. 04. 1945.

BCA: 030. 10/177. 224. 7/ 19. 03. 1946.

BCA: 030. 01/ 65. 401. 6/ 17.01. 1946.

BCA: No: 189. 2. 09. 1946.

BCA: 030. 01./ 78. 487. 9/26. 09. 1946. 